\title{
Biotechnical development of genetic addiction risk score (GARS) and selective evidence for inclusion of polymorphic allelic risk in substance use disorder (SUD)
}

\author{
Blum K ${ }^{1-9 *}$, Bowirrat $\mathrm{A}^{10}$, Baron D ${ }^{1}$, Lott L ${ }^{2}$, Ponce JV ${ }^{2}$, Brewer R ${ }^{2}$, Siwicki D ${ }^{2}$, Boyett B ${ }^{5}$, Gondre-Lewis MC ${ }^{11,12}$, Smith DE ${ }^{13}$, Panayotis K Thanos ${ }^{14}$, \\ Badgaiyan $S^{2}$, Hauser $M^{3}$, Fried $L^{15}$, Roy A. $111{ }^{16}$, Downs BW ${ }^{4}$ and Badgaiyan RD ${ }^{17-19}$ \\ ${ }^{1}$ Western University Health Sciences Graduate School of Biomedical Sciences, Pomona, CA, USA \\ ${ }^{2}$ Department of Precision Behavioral Management, Geneus Health, San Antonio, TX, USA \\ ${ }^{3}$ Division Addiction Services, Dominion Diagnostics, LLC, North Kingston, RI, USA \\ ${ }^{4}$ Division of Nutrigenomics, Victory Nutrition International. Inc. Lederach, PA, USA \\ ${ }^{5}$ Divion of Neuroscience \& Addiction Research, Pathway HealthCare, LLC, Birmingham, AL \\ ${ }^{6}$ Institute of Psychology, ELTE Eötvös Loránd University, Budapest, Hungary \\ ${ }^{7}$ Department of Psychiatry, University of Vermont, Burlington, VM. USA \\ ${ }^{8}$ Centre for Genomics and Applied Gene Technology, Institute of Integrative Omics and Applied Biotechnology, Nonakuri, Purba Medinipur, West Bengal, India \\ ${ }^{9}$ Department of Psychiatry, Wright State University Boonshoft School of Medicine and Dayton VA Medical Centre, Dayton, OH, USA \\ ${ }^{10}$ Departments of Clinical Neuroscience and Population Genetics, Interdisciplinary Center (IDC) Herzliya, Department of Neuroscience, Israel \\ ${ }^{11}$ National Human Genome Center, Howard University, Washington DC, USA \\ ${ }^{12}$ Departments of Anatomy, and Psychiatry \& Behavioral Sciences, Howard University College of Medicine, Washington DC, USA \\ ${ }^{13}$ Department of Pharmacology, University of California San Francisco School of Medicine, San Francisco, USA \\ ${ }^{14}$ Behavioral Neuropharmacology and Neuroimaging Laboratory on Addictions, Research Institute on Addictions, University at Buffalo, Buffalo, NY, USA \\ ${ }^{15}$ Transformations Treatment Center, Del-Ray Beach, FL, USA \\ ${ }^{16}$ Department of Psychiatry, Tulane University School of Medicine, New Orleans, LA, USA \\ ${ }^{17}$ Department of Psychiatry, Ichan School of Medicine at Mount Sinai, New York, NY., USA \\ ${ }^{18}$ Department of Psychiatry, South Texas Veteran Health Care System, Audie L. Murphy Memorial VA Hospital, San Antonio, TX, USA \\ ${ }^{19}$ Long School of Medicine, University of Texas Medical Center, San Antonio, USA²Instituto Nacional de Neurología y Neurocirugía
}

\begin{abstract}
Research into the neurogenetic basis of addiction identified and characterized by Reward Deficiency Syndrome (RDS) includes all drug and non-drug addictive, obsessive and compulsive behaviors. We are proposing herein that a new model for the prevention and treatment of Substance Use Disorder (SUD) a subset of RDS behaviors, based on objective biologic evidence, should be given serious consideration in the face of a drug epidemic. The development of the Genetic Addiction Risk Score (GARS) followed seminal research in 1990, whereby, Blum's group identified the first genetic association with severe alcoholism published in JAMA. While it is true that no one to date has provided adequate RDS free controls there have been many studies using case -controls whereby SUD has been eliminated. We argue that this deficiency needs to be addressed in the field and if adopted appropriately many spurious results would be eliminated reducing confusion regarding the role of genetics in addiction. However, an estimation, based on these previous literature results provided herein, while not representative of all association studies known to date, this sampling of case- control studies displays significant associations between alcohol and drug risk. In fact, we present a total of 110,241 cases and 122,525 controls derived from the current literature. We strongly suggest that while we may take argument concerning many of these so-called controls (e.g. blood donors) it is quite remarkable that there are a plethora of case -control studies indicating selective association of these risk alleles ( measured in GARS) for the most part indicating a hypodopaminergia. The paper presents the detailed methodology of the GARS. Data collection procedures, instrumentation, and the analytical approach used to obtain GARS and subsequent research objectives are described. Can we combat SUD through early genetic risk screening in the addiction field enabling early intervention by the induction of dopamine homeostasis? It is envisaged that GARS type of screening will provide a novel opportunity to help identify causal pathways and associated mechanisms of genetic factors, psychological characteristics, and addictions awaiting additional scientific evidence including a future meta- analysis of all available data - a work in progress.
\end{abstract}

${ }^{\star}$ Correspondence to: Kenneth Blum, Research Professor, Western University Health Sciences Graduate School of Biomedical Sciences, Pomona, CA, USA, E-mail: Drd2gene@gmail.com

Key words: substance use disorder (sud), genetic addiction risk score (gars $\left.{ }^{\star}\right)$, dopamine. brain reward circuitry, precision addiction management (pam ${ }^{\circledR}$ ), reward deficiency syndrome ( $r d s)$

Received: December 02, 2019; Accepted: December 16, 2019; Published: December 19, 2019 
Abbreviations: SNP: Single Nucleotide Polymorphism; VNTRs: Variable Number Tadem Report.

\section{Introduction}

\section{History of Reward Deficiency Syndrome (RDS) development}

Research into the neurogenetic basis of addiction identified and characterized by Reward Deficiency Syndrome (RDS) [1] includes all drug and non-drug addictive, obsessive and compulsive behaviors. We are proposing herein that a new model for the prevention and treatment of RDS behaviors based on objective biologic evidence should be given serious consideration in the face of a drug epidemic [2]. Currently, research directed toward improving treatment for highly drugdependent patients in underserved populations represents one example of adoption of this bold concept and is under study through a NIH grant [3]. The grant explores utilization of the Genetic Addiction Risk Score (GARS) and the neuronutrient pro-dopamine regulator KB220.

The development of GARS followed seminal research in 1990, whereby, Blum's group identified the first genetic association with severe alcoholism published in JAMA [4]. The non-invasive GARS test identifies and measures the total number of risk alleles of genes and catabolic enzymes affecting an individual's neurochemical hypodopaminergic function and has been associated in hundreds of studies with SUD [5].

According to the American Society of Addiction Medicine (ASAM), addiction is a "primary, chronic disease of brain reward, motivation, memory and related circuitry." This defintion communicates the many effects of addiction, but the factors that can increase the risk of addiction are also varied, including: genetic predisposition, comorbid psychiatric conditions, and certain at-risk environments. Addiction is a broad term that can refer to substance addiction (e.g., opioids, prescription drugs) and non-substance addiction (e.g., thrill seeking, gambling) [6].
The mesolimbic pathway, the "reward pathway," (Figure 1) is a dopaminergic pathway in the brain. The pathway connects the ventral tegmental area (VTA) in the midbrain to the ventral striatum (includes the nucleus accumbens (NAc) and the olfactory tubercle) of the basal ganglia in the forebrain. Release of dopamine (DA) (via signaling involving serotonin, endocannabinoids, enkephalin and GABA) from the mesolimbic pathway to the NAc regulates motivation and desire for reward stimuli. Drug and alcohol use can boost DA, a neurotransmitter that helps produce pleasurable feelings, thus promoting more cravings. As a person continues to abuse substances, the brain adapts by reducing the ability of cells in the reward circuit to respond to it. This reduces the euphoria that the person feels, inducing tolerance. Depletion of DA in this pathway, or lesions at its site of origin, or even serotonin depletion, decrease the extent to which an animal is willing to go to obtain a reward [7]. Brain adaptations often lead the person to become less able to derive pleasure from other things they once enjoyed (the thrill is gone). Continual long-term abuse of substances can cause changes to other brain chemical systems, affecting functions that include: learning, judgement, decision-making, and beahvior.

Following nearly three decades of genetic-based research related to identifying and characterizing addiction-related behavior, one of us (KB) coined the term "Reward Deficiency Syndrome." Reward Deficiency Syndrome (RDS) is used to portray behaviors found to have gene-based association with hypo-dopaminergic function [8]. Among the literature that associate polymorphisms of reward genes with risk of RDS behaviors, the dopamine D2 receptor (DRD2) gene is one of the most widely studied as a receptor type. However, other genes are also involved, and it has been adequately established in association studies and animal research literature that, for example, polymorphisms of the serotonergic-2 A receptor and the catechol-O-methyltransferase genes pre-dispose individuals to aberrant RDS behaviors [9]. RDS, listed as a psychological disorder in the Sage Encyclopedia for Abnormal Psychology (2017), has gained wide acceptance in the scientific community, as a crucial factor in the etiology of all types of addictive,

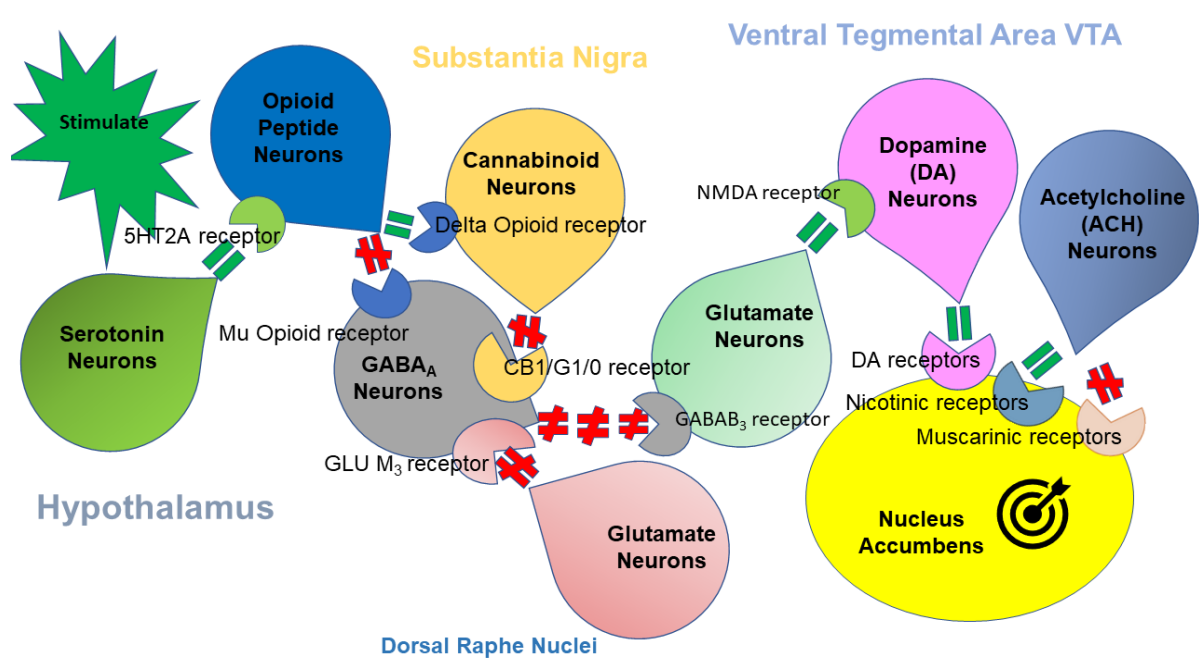

Figure 1. The brain reward cascade (BRC). Figure1 illustrates the interaction of at least six principal neurotransmitter pathways involved in the Brain Reward Cascade (BRC). In the hypothalamus, environmental stimulation causes the release of serotonin, which in turn via, for example, 5HT-2a receptors activate (green, equal sign) the subsequent release of opioid peptides also in the hypothalamus. Then, in turn, the opioid peptides having two distinct effects possibly via two different opioid receptors: A) inhibits (red hash sign) through the mu-opioid receptor (possibly via enkephalin) and projects to the Substania Nigra to GABA neurons B) stimulates (green equal sign) Cannabinoid neurons (e.g., Anandamide and 2-archydonoglcerol) through Beta-Endorphin linked delta receptors, which in turn inhibits $\mathrm{GABA}_{\mathrm{A}}$ neurons at the substania nigra. Cannabinoids primarily 2 -archydonoglcerol, when activated, can also indirectly disinhibit (red hash sign) GABA $A_{A}$ neurons in the Substania Nigra through activation of G1/0 coupled to CB1 receptors. Similarly, Glutamate neurons located in the Dorsal Raphe Nucle (DRN) can indirectly disinhibit GABA neurons in the Substania Nigra through activation of GLU M receptors (red hash sign). GABA neurons, when stimulated, will, in turn, powerfully (red hash signs) inhibit VTA glutaminergic drive via GABAB ${ }_{3}$ neurons. Finally, Glutamate neurons in the VTA will project to dopamine neurons through NMDA receptors (green, equal sign) to preferentially release dopamine at the Nucleus Accumbens (ACH)shown as a bullseye indicating euphoria (a wanting response) 
Blum K (2019) Biotechnical development of genetic addiction risk score (GARS) and selective evidence for inclusion of polymorphic allelic risk in substance use disorder (SUD)

compulsive, and obsessive behaviors, like substance, and non-substance addictive behaviors, like gambling and gaming [10].

There are different strategies for managing addiction. One strategy is prevention of drug use. Principles of prevention of addiction advocates for early intervention (National Institute on Drug Abuse: Lessons from Prevention Research) and identifying risks at an early age [11]. Environmental factors and the induction of epigenetics can increase risk of addiction, so being aware what may be a risk factor for drug use may help individuals for prevention and in developing effective protective strategies [12].

Another strategy for managing addiction is to prevent relapse. People in recovery from substance use disorders are at an increase risk for relapse, even after years of not taking the substance. Relapse for substance use disorder is comparable to other chronic illnesses, such as hypertension and asthma [13]. In spite of over almost three decades of psychiatric genetic research with its 22,961 articles listed in Pubmed (12-1-19), and even after 17 years of addiction directed genetic research,
Els [14] suggested that a number country's public thinks of addiction as a moral failing rather than a medical condition, likely exacerbating the guilt and shame that recovering individuals experience.

\section{Rationale for GARS allelic selection}

Since 1990 the field related to genetics of addiction has the state as of and Uhls' group [15] provided a snapshot showing the state of the as of 2011, indicating the complex nature of genes linked to addictive behaviors particularly SUD. Figure 2 shows the overall pipeline of a meta-analyses of addiction-associated genetic variations, genomewide analysis of the molecular mechanisms of implicated SNPs, and the pathways and gene interaction networks that might involve these genetic factors.

Meta-analyses of candidate gene association studies and GWAS were illustrated in detail in STEP 1. In total, 843 vulnerable haplotypes were identified, linked by 12 risk variants and 842 vulnerable SNPs. All data and knowledge were imported to an updated version of the knowledgebase for addiction-related genes (KARG 2.0, marked with

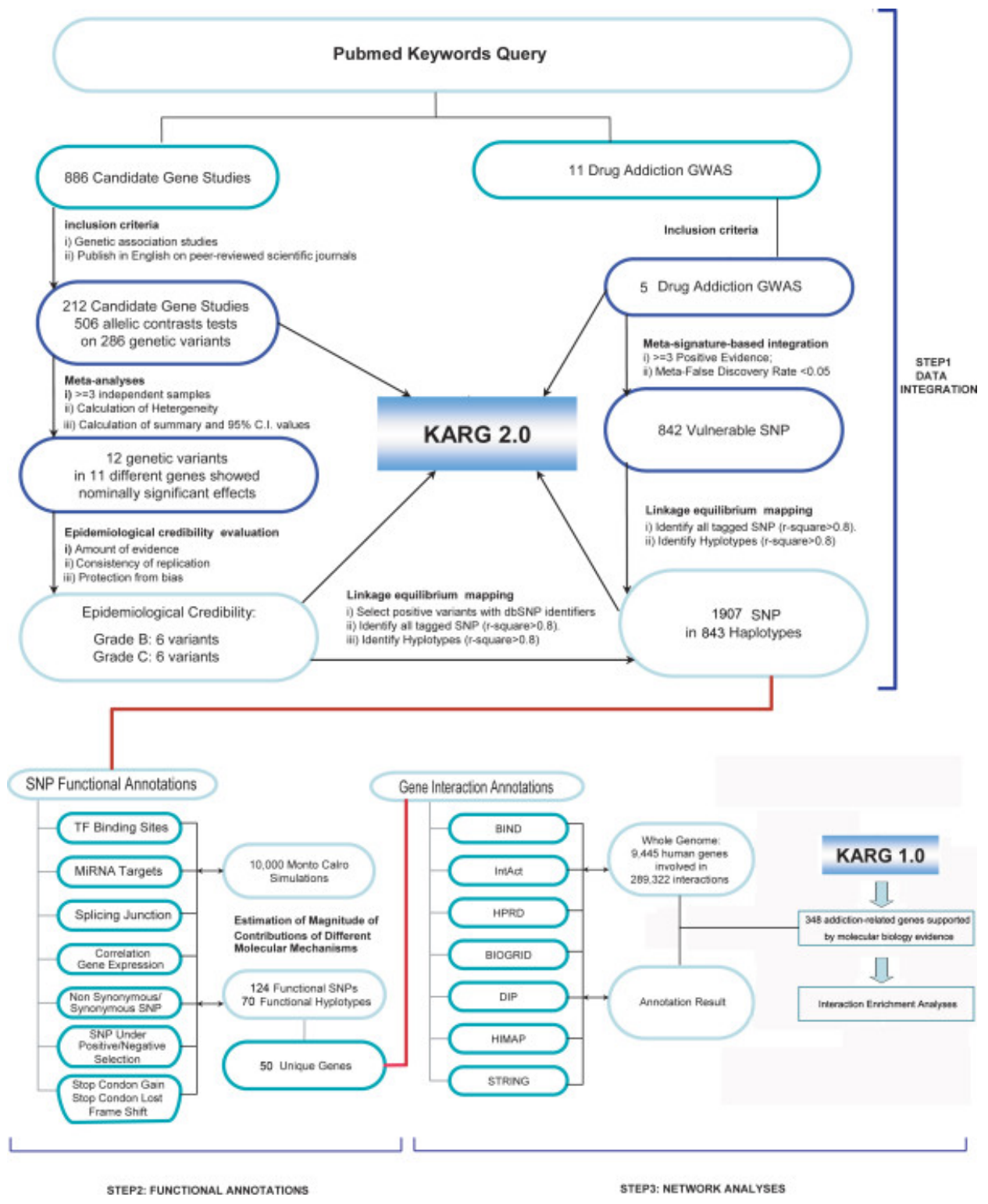

Figure 2. Pipelines for meta-analyses, functional SNP annotations and interaction analyses (with permission) 
a blue box). Haplotypes identified in STEP 1 were annotated with functional and regulatory elements (STEP 2). Taken from interaction enrichment analyses between the susceptibility genes and addictionregulated genes previously identified by molecular biology studies (KARG 1.0, marked with a blue box) were performed (STEP 3).

While the entire molecular biological community is interested in genetic risk for alcohol and substance addiction, and personalized medicine, presently, many are not aware of a genetic panel that demonstrates significant predictability to clinical risk. To this aim, we are highlighting this rather new and unique genetic test to provide this community an up-to date knowledge base. A Pubmed search for each gene represented in the GARS on 6-8-19 returned the following results (Table 1).

While it is true that no one to date has provided adequate RDS free controls there have been many studies using case -controls whereby SUD has been eliminated. We argue that this deficiency needs to be addressed in the field and if adopted appropriately many spurious results would be eliminated and as such it will reduce confusion providing a clearer understanding and an overhaul of the current state of the art of genetics underlining all addictive behaviors drug and nondrug or RDS. In Figure 3 we display the current polymorphic risk alleles of the GARS panel.

In addition we have highlighted a number of meta-analyses (if found) for each risk allele selected in GARS to point out a clear

Table 1. Population number of PUBMED listed studies per gene as of 6-12-19

\begin{tabular}{|c|c|c|}
\hline Name & PubMed Listed Protein & PubMed Listed Gene \\
\hline SEROTONIN TRANSPORTER & 10,146 & 4,532 \\
\hline COMT & 4,879 & 2,785 \\
\hline MONAMINE OXIDASE - A & 23,063 & 1,899 \\
\hline DOPAMINE D1 RECEPTOR & 12,249 & 1,791 \\
\hline DOPAMINE D2 RECEPTOR & 23,020 & 4,724 \\
\hline DOPAMINE D3 RECEPTOR & 4,037 & 857 \\
\hline DOPAMINE D4 RECEPTOR & 2499 & 1,294 \\
\hline DOPAMINE TRANSPORTER & 10,586 & 2,830 \\
\hline OPIOID MU RECEPTOR & 13,854 & 1,873 \\
\hline GABA RECEPTOR(s) & 29,004 & 3,745 \\
\hline TOTAL & 133,337 & 26,330 \\
\hline
\end{tabular}

association compared to non-SUD controls and experimental SUD probands. Specifically, the genetic panel was selected for polymorphisms of a number of reward genes that have been correlated with chronic dopamine deficiency and drug related reward-seeking behavior.

An estimation based on these results herein, while not representative of all association studies known to date, of case- control studies provides significant associations whereby there are a total of 110,241 cases and 122,525 controls. A review of the related Figure 3 strongly suggest that while we may take argument concerning many of these so-called controls (e.g. blood donors) it is quite remarkable that there are a plethora of case -control studies indicating selective association of these risk alleles (measured in GARS) for the most part indicating a hypodopaminergia. Based on these results, we feel confident that albeit not having RDS free controls, there is sufficient evidence that each risk allele displayed in GARS relative to non-SUD controls associate as risk for prediction for drug and alcohol severity and dependence (Table 2).

Awareness of biological and environmental factors can impact a person's risk of addiction. Scientists estimate that heritabilities of addictive disorders can range from $30-50 \%$ or possibly higher, depending on the substance [16]. Being cognizant of the biological risk may help individuals develop protective factors and help individuals see addiction as a medical condition. Additionally, standard tests, like the Addiction Severity Index [17] or Opioid Risk Tool [18], coupled with genetic polymorphic risk testing can help enhance understanding and achieve a personal medicine approach for each patient

\section{Methods and materials - Device description}

The Genetic Addiction Risk Score (GARS) test is a non-diagnostic, DNA genetic testing tool. The Genetic Addiction Risk Score (GARS) is based on a qualitative genetic test for single nucleotide polymorphism detection of Substance Use Disoerder (SUD). We are detailing the methodology of the GARS test to provide the readerdhip with this important information and thereby reduce questions.

\section{Sample collection and processing utilized to obtain data}

Buccal cells are collected from each patient using an established minimally invasive collection kit. Sterile Copan 4N6FLOQ Swabs

Table 2. Represents the GARS Polymorphisms and only positive case -control association and longitudinal studies

\begin{tabular}{|c|c|c|c|c|}
\hline Gene & Poly-morphism & Association & Case-Control & Reference \\
\hline \multirow[t]{3}{*}{ DRD1 } & Rs4532 & $\begin{array}{l}\text { Rs } 4532 \text { could predict decreased post- } \\
\text { opioid dependence pleasure. }\end{array}$ & $\begin{array}{l}\text { The present study included } \mathrm{N}=425 \text { unrelated } \\
\text { opioid addicts registered in the Methadone } \\
\text { Maintenance Treatment Program at Xi'an Mental } \\
\text { Health Center of China. The OD diagnosis was } \\
\text { established using DSM-IV criteria and based on } \\
\text { medical record, urine test, and interview. The } \\
\text { controls consisted of N=514 unrelated healthy } \\
\text { persons who had never been diagnosed with } \\
\text { substance abuse and mental illness. }\end{array}$ & $\begin{array}{l}\text { Zhu F (2013) Dopamine D1 receptor } \\
\text { gene variation modulates opioid } \\
\text { dependence risk by affecting transition } \\
\text { to addiction. PloS one } 8: \text { e } 70805 .\end{array}$ \\
\hline & Rs4532 & $\begin{array}{l}\text { Statistically significant associations of } \\
\text { polymorphisms in DRD1 rs } 4532 \text { with } \\
\text { alcoholism were found. }\end{array}$ & $\begin{array}{l}\text { In another study } \mathrm{N}=140 \text { male alcohol dependent } \\
\text { subjects attending the outpatient department } \\
\text { (OPD) at National Drug Dependence Treatment } \\
\text { Centre, AIIMS, were screened. A total of } \mathrm{N}=122 \\
\text { unrelated healthy male employees of the hospital, } \\
\text { without any history of substance use (except } \\
\text { nicotine) were included as controls in the study. }\end{array}$ & $\begin{array}{l}\text { Prasad P (2013). Case-control } \\
\text { association analysis of dopamine } \\
\text { receptor polymorphisms in alcohol } \\
\text { dependence: a pilot study in Indian } \\
\text { males. BMC research notes, } 6,418 \text {. } \\
\text { doi:10.1186/1756-0500-6-418 }\end{array}$ \\
\hline & Rs4532 & $\begin{array}{l}\text { A specific haplotype rs } 686^{*} \mathrm{~T}- \\
\text { rs } 4532 * \mathrm{G} \text { within the } \mathrm{DRD} 1 \text { gene was } \\
\text { significantly more precisely associated } \\
\text { with alcohol dependence in our sample } \\
(\mathrm{p}=5 \times 10(-6)) \text {. }\end{array}$ & $\begin{array}{l}\text { A third study analyzed a population of } 134 \\
\text { patients with alcohol dependence, also assessing } \\
\text { more homogeneous (severe) phenotypes, } \\
\text { comparing this sample with a healthy control } \\
\text { population, assessing two SNPs within the } \\
\text { DRD1 gene in order to depict the role of DRD1 } \\
\text { polymorphisms and haplotypes }\end{array}$ & $\begin{array}{l}\text { Batel P, Houchi H, Daoust M, Ramoz } \\
\mathrm{N}, \text { Naassila M, Gorwood P. A haplotype } \\
\text { of the DRD1 gene is associated with } \\
\text { alcohol dependence. Alcohol Clin } \\
\text { Exp Res. 2008 Apr;32(4):567-72. doi: } \\
\text { 10.1111/j.1530-0277.2008.00618.x. }\end{array}$ \\
\hline
\end{tabular}


Blum K (2019) Biotechnical development of genetic addiction risk score (GARS) and selective evidence for inclusion of polymorphic allelic risk in substance use disorder (SUD)

\begin{tabular}{|c|c|c|c|c|}
\hline \multirow[t]{3}{*}{ DRD2 } & Rs1800497 & $\begin{array}{l}\text { DRD2/ANKK1 TaqIA polymorphism } \\
\text { was significantly associated with } \\
\text { increased risk of opioid dependence } \\
\text { under homozygote, dominant, } \\
\text { and recessive genetic model, } \\
\text { respectively (homozygote: } \mathrm{OR}=1.546 \text {, } \\
95 \% \mathrm{CI}=1.279-1.87 \text {; dominant: } \\
\mathrm{OR}=1.265,95 \% \mathrm{CI}=1.055-1.516 \text {; } \\
\text { recessive: } \mathrm{OR}=1.409,95 \% \mathrm{CI}=1.182 \text { - } \\
1.680 \text { ). }\end{array}$ & $\begin{array}{l}\text { A total of } 25 \text { available case-control studies testing } \\
\text { the association between the polymorphism and } \\
\text { common illicit drug dependence were examined } \\
\text { through Oct } 2013 \text {. Pooled odds ratios (ORs) and } \\
95 \% \text { confidence intervals (CI) were estimated } \\
\text { using fixed- and random-effects models when } \\
\text { appropriate. }\end{array}$ & $\begin{array}{l}\text { Deng XD (2015) Association between } \\
\text { DRD2/ANKK1 TaqIA polymorphism } \\
\text { and common illicit drug dependence: } \\
\text { evidence from a meta-analysis. Hum } \\
\text { Immunol. 2015 Jan;76(1):42-51. } \\
\text { doi:10.1016/j.humimm.2014.12.005. }\end{array}$ \\
\hline & Rs1800497 & $\begin{array}{l}\text { TaqI A1 polymorphism was } \\
\text { significantly increased for opioid } \\
\text { dependence risk (homozygote } \\
\text { comparison: OR, } 2.06 \text {; } 95 \% \text { CI, } 1.25- \\
\text { 3.42; dominant comparison: OR, } 1.34 \text {; } \\
95 \% \text { CI, 1.08-1.67). }\end{array}$ & $\begin{array}{l}\text { A meta-analysis, including } \mathrm{N}=6,846 \text { opioid } \\
\text { dependence cases and } \mathrm{N}=4,187 \text { controls from } 22 \\
\text { individual studies }\end{array}$ & $\begin{array}{l}\text { Chen D, Liu F, Shang Q, Song X, } \\
\text { Miao X, Wang Z. Association between } \\
\text { polymorphisms of DRD2 and DRD4 } \\
\text { and opioid dependence: evidence } \\
\text { from the current studies. Am J Med } \\
\text { Genet B Neuropsychiatr Genet. } \\
\text { 2011;156B(6):661-70. doi: } 10.1002 / \\
\text { ajmg.b.31208. }\end{array}$ \\
\hline & Rs1800497 & $\begin{array}{l}\text { rs } 1800497 \text { was significantly } \\
\text { associated in men with excessive } \\
\text { alcohol consumption. }\end{array}$ & $\begin{array}{l}\text { The study sample }(\mathrm{N}=1533 \text {, of which } 746 \text { were } \\
\text { women) consisted of } 653 \text { heavy consumers } \\
\text { and } \mathrm{N}=880 \text { very low consumers from the } \\
\text { Spanish sub-cohort of the European Prospective } \\
\text { Investigation into Cancer and Nutrition (EPIC) } \\
\text { cohort. }\end{array}$ & $\begin{array}{l}\text { Celorrio D, Muñoz X, Amiano P, } \\
\text { Dorronsoro M, Bujanda L, Sánchez } \\
\text { MJ, Molina-Montes E, Navarro C, } \\
\text { Chirlaque MD, MaríaHuerta J, Ardanaz } \\
\text { E, Barricarte A, Rodriguez L, Duell EJ, } \\
\text { Hijona E' Herreros-Villanueva M, Sala } \\
\text { N ·Alfonso-Sánchez MA, de Pancorbo } \\
\text { MM. Influence of Dopaminergic } \\
\text { System Genetic Variation and } \\
\text { Lifestyle Factors on Excessive Alcohol } \\
\text { Consumption. Alcohol Alcohol. 2016 } \\
\text { May;51(3):258-67. doi: 10.1093/alcalc/ } \\
\text { agv114. }\end{array}$ \\
\hline & Rs1800497 & $\begin{array}{l}\text { Genetic variation in rs } 1800497 \text { play } \\
\text { an equal role in predicting alcohol } \\
\text { drinking two years later and are most } \\
\text { important in predicting the increase in } \\
\text { alcohol consumption }\end{array}$ & $\begin{array}{l}\text { Examined } \mathrm{N}=736 \text { adolescents from the IMAGEN } \\
\text { longitudinal study for alcohol drinking during } \\
\text { early (mean age }=14.37 \text { ) and again later (mean } \\
\text { age }=16.45 \text { ) adolescence. }\end{array}$ & $\begin{array}{l}\text { Heinrich A, IMAGEN consortium. } \\
\text { Prediction of alcohol drinking in } \\
\text { adolescents: Personality-traits, behavior, } \\
\text { brain responses, and genetic variations } \\
\text { in the context of reward sensitivity. } \\
\text { Biol Psychol. } 2016 ; 118: 79-87 \text {. doi: } \\
\text { 10.1016/j.biopsycho.2016.05.002. }\end{array}$ \\
\hline & Rs1800497 & $\begin{array}{l}\text { Rs } 1800497 \text { genotype distribution is } \\
\text { significantly associated to Alcohol } \\
\text { Dependence }(O . R .=1.551, p=0.023) \text {, } \\
\text { with A1* allele displaying an } \\
\text { O.R. }=1.403(p=0.029) \text {. }\end{array}$ & $\begin{array}{l}\text { The study design was a case-control. In total, } \mathrm{N}=- \\
280 \text { alcoholic subjects }(213 \text { men and } 67 \text { woman }) \\
\text { and } \mathrm{N}=280 \text { age- and sex-matched control subjects } \\
\text { were recruited for this study }\end{array}$ & $\begin{array}{l}\text { Mignini F, Napolioni V, Codazzo } \\
\text { C, Carpi FM, Vitali M, Romeo M, } \\
\text { Ceccanti M. DRD2/ANKK1 TaqIA } \\
\text { and SLC6A3 VNTR polymorphisms } \\
\text { in alcohol dependence: association } \\
\text { and gene-gene interaction study in a } \\
\text { population of Central Italy. Neurosci } \\
\text { Lett. 2012;;522(2):103-7. doi: } \\
\text { 10.1016/j.neulet.2012.06.008. }\end{array}$ \\
\hline & Rs1800497 & $\begin{array}{l}\text { Homozygous genotype variants (A1A1 } \\
1 \text { A2A2) were over-represented in case } \\
\text { groups compared to controls, while } \\
\text { heterozygotes were more frequently } \\
\text { observed in control group, but no } \\
\text { statistically significant difference was } \\
\text { found. Analysis of genotype A1A1 } \\
\text { frequency showed } 6 \% \text { and } 2 \% \text { in } \\
\text { case and control groups respectively. } \\
\text { Statistical analysis pointed statistically } \\
\text { significant overrepresentation of A1A1 } \\
\text { genotype in case group, as opposed } \\
\text { to expected -normal distribution with } \\
\text { controls (OR=1.532 (CI=1.001-2.344) } \\
\text { i } p<0.05 . \text { This implies that A1A1 } \\
\text { carriers have } 1.5 \text { fold increased risk } \\
\text { for development of heroin addiction } \\
\text { with } 30-40 \% \text { lower D2 receptors }\end{array}$ & $\begin{array}{l}\text { } 100 \text { patients on Metadone Maintenance Treatment } \\
\text { (MMT) and } 100 \text { age and sex matched healthy } \\
\text { volunteers }\end{array}$ & $\begin{array}{l}\text { Mehić-Basara, N, Oruč, L, Kapur- } \\
\text { Pojskić, L, Ramić, J. (2013). } \\
\text { Association of dopamine receptor } \\
\text { gene polymorphism and psychological } \\
\text { personality traits in liability for opioid } \\
\text { addiction. Bosnian journal of basic } \\
\text { medical sciences, 13(3), 158-162. } \\
\text { doi:10.17305/bjbms.2013.2355 }\end{array}$ \\
\hline & Rs 1800497 & $\begin{array}{l}\text { In single marker analysis the TaqIA } \\
\text { (rs1800497) and TaqIB (rs1079597) } \\
\text { variants were associated with heroin } \\
\text { dependence }\end{array}$ & $\begin{array}{l}303 \text { heroin dependent subjects and } 555 \text { healthy } \\
\text { controls were genotyped for rs } 1800497 \text { and TaqIB } \\
\text { (rs1079597) }\end{array}$ & $\begin{array}{l}\text { Vereczkei A, Demetrovics Z, Szekely A, } \\
\text { Sarkozy P, Antal P, Szilagyi A, Sasvari- } \\
\text { Szekely M, Barta C. Multivariate } \\
\text { analysis of dopaminergic gene variants } \\
\text { as risk factors of heroin dependence. } \\
\text { PLoS One. 2013 Jun 28;8(6):e66592. } \\
\text { doi: 10.1371/journal.pone.0066592. } \\
\text { PubMed PMID: 23840506; PubMed } \\
\text { Central PMCID: PMC3696122. }\end{array}$ \\
\hline
\end{tabular}


Blum K (2019) Biotechnical development of genetic addiction risk score (GARS) and selective evidence for inclusion of polymorphic allelic risk in substance use disorder (SUD)

\begin{tabular}{|c|c|c|c|c|}
\hline & Rs1800497 & $\begin{array}{l}\text { A random/fixed-effects meta-analyses } \\
\text { using allelic contrasts found that } \\
\text { the TaqIA (rs1800497) significantly } \\
\text { associated with addiction at }<0.0001\end{array}$ & $\begin{array}{l}\text { A meta-analytic comparison of single marker } \\
\text { analysis of the TaqIA (rs1800497), whereas A2 } \\
\text { was compared to A1 in } 6312 \text { Cases vs. } 7424 \\
\text { Controls in } 20 \text { independent studies }\end{array}$ & $\begin{array}{l}\text { Li CY, Zhou WZ, Zhang PW, Johnson } \\
\text { C, Wei L, Uhl GR. Meta-analysis and } \\
\text { genome-wide interpretation of genetic } \\
\text { susceptibility to drug addiction. BMC } \\
\text { Genomics. 2011 Oct 15;12:508. doi: } \\
\text { 10.1186/1471-2164-12-508. PubMed } \\
\text { PMID: 21999673; PubMed Central } \\
\text { PMCID: PMC3215751. }\end{array}$ \\
\hline & Rs1800497 & $\begin{array}{l}\text { Meta-analysis demonstrated both } \\
\text { allelic and genotypic association } \\
\text { between the Taq1A polymorphism } \\
\text { and AD susceptibility [allelic: } \\
P(Z)=1.1 \times 10^{-5}, \mathrm{OR}=1.19 \text {; genotypic: } \\
\left.P(Z)=3.2 \times 10^{-5}, \mathrm{OR}=1.24\right] \text {. The } \\
\text { association remained significant after } \\
\text { adjustment for publication bias using } \\
\text { the trim and fill method }\end{array}$ & $\begin{array}{l}\text { A large-scale meta-analysis to confirm the } \\
\text { association between the Taq1A polymorphism and } \\
\text { the risk for AD in over } 18,000 \text { subjects included } \\
\text { in } 61 \text { case-control studies that were published up } \\
\text { to August } 2012\end{array}$ & $\begin{array}{l}\text { Wang F, Simen A, Arias A, Lu QW, } \\
\text { Zhang H. A large-scale meta-analysis } \\
\text { of the association between the ANKK1/ } \\
\text { DRD2 Taq1A polymorphism and } \\
\text { alcohol dependence. Hum Genet. } 2013 \\
\text { Mar;132(3):347-58. doi: } 10.1007 / \\
\text { s00439-012-1251-6. Epub 2012 Dec } \\
\text { 1. PubMed PMID: 23203481; PubMed } \\
\text { Central PMCID: PMC3570676. }\end{array}$ \\
\hline \multirow[t]{5}{*}{ DRD3 } & $\begin{array}{l}\text { DRD3 Ser9Gly } \\
\text { polymorphism (rs6280) }\end{array}$ & $\begin{array}{l}\text { Linear regression analysis controlling } \\
\text { for age, sex, diagnosis, and self- } \\
\text { reported anhedonia indicated that } \\
\text { during receipt of unpredictable } \\
\text { monetary reward the glycine allele } \\
\text { was associated with a greater } \\
\text { reduction in } \mathrm{D} 2 / 3 \text { receptor binding } \\
\text { (i.e. increased reward-related DA } \\
\text { release) in the middle caudate }\left(\mathrm{r}^{2}\right. \\
\text { explained }=0.24, \beta \text {-weight }=0.5, \mathrm{t}=3.3 \text {, } \\
\mathrm{p}=0.003) \text { and the ventral striatum }\end{array}$ & $\begin{array}{l}\text { Twenty-six right-handed HCs ( } 15 \text { women; } \\
\text { mean age } 34.4 \pm 8.3 \text { ) and } 10 \text { currently depressed, } \\
\text { unmedicated patients with MDD ( } 8 \text { women; mean } \\
\text { age } 38.2 \pm 11.3 \text { ) participated in the study }\end{array}$ & $\begin{array}{l}\text { Savitz J, Hodgkinson CA, Martin- } \\
\text { Soelch C, et al, The functional DRD3 } \\
\text { Ser9Gly polymorphism (rs6280) is } \\
\text { pleiotropic, affecting reward as well } \\
\text { as movement. PLoS one, 8:e54108, } \\
\text { (2013). }\end{array}$ \\
\hline & rs6280 & $\begin{array}{l}\text { This SNP was significantly associated } \\
\text { with both } \mathrm{AD} \text { overall }(\chi(2)=10.09 \\
\text { and } \mathrm{p}=0.001 \text {, and } \chi(2)=10.60 \text { and } \mathrm{p} \\
=0.005 \text {, for the recessive and additive } \\
\text { models, respectively) and with Lesch } \\
\text { type I AD }(\chi(2)=11.70 \text { and } \mathrm{p}=0.001 \text {, } \\
\text { and } \chi(2)=11.70 \text { and } \mathrm{p}=0.003 \text {, for } \\
\text { the recessive and additive models, } \\
\text { respectively). The findings of this } \\
\text { study suggest that the DRD } 3 \text { rs } 6280 \\
\text { polymorphism is associated with the } \\
\text { development of both AD overall and } \\
\text { Lesch type I AD }\end{array}$ & $\begin{array}{l}\text { The DRD3 rs6280 SNP was genotyped in a } \\
\text { case-control sample comprising } 245 \text { AD patients } \\
\text { and } 130 \text { healthy controls (HCs). Alcohol Use } \\
\text { Disorders Identification Test (AUDIT) scores } \\
\text { were also compared relative to genotype in all of } \\
\text { the participants. }\end{array}$ & $\begin{array}{l}\text { Kang SG, Lee BH, Lee JS, Chai } \\
\text { YG, Ko KP, Lee HJ, Han DM, Ji } \\
\text { H, Jang GH, Shin HE. DRD3 gene } \\
\text { rs6280 polymorphism may be } \\
\text { associated with alcohol dependence } \\
\text { overall and with Lesch type I } \\
\text { alcohol dependence in Koreans. } \\
\text { Neuropsychobiology. } 2014 ; 69(3): 140-6 \text {. } \\
\text { doi: } 10.1159 / 000358062 \text {. }\end{array}$ \\
\hline & rs6280 & $\begin{array}{l}\text { The rs } 6280 \text { and rs } 9825563 \text { variants } \\
\text { showed association with the } \\
\text { development of early-onset heroin } \\
\text { dependence. Authors suggest DRD3 } \\
\text { is possibly a genetic factor in the } \\
\text { development of early-onset heroin } \\
\text { dependence }\end{array}$ & $\begin{array}{l}\text { Eight polymorphisms in DRD3 were analyzed } \\
\text { in } 1067 \text { unrelated Han Chinese subjects ( } \mathrm{N}=566 \\
\text { heroin dependence patients and } \mathrm{N}=501 \text { controls). } \\
\text { All participants were screened using the same } \\
\text { assessment tool and all patients met the criteria } \\
\text { for heroin dependence }\end{array}$ & $\begin{array}{l}\text { Kuo SC, Yeh YW, Chen CY, Huang } \\
\text { CC, Chang HA, Yen CH, Ho PS, } \\
\text { Liang CS, Chou HW, Lu RB, Huang } \\
\text { SY. DRD3 variation associates with } \\
\text { early-onset heroin dependence, } \\
\text { but not specific personality traits. } \\
\text { Prog Neuropsychopharmacol Biol } \\
\text { Psychiatry. 2014 Jun 3;51:1-8. doi: } \\
\text { 10.1016/j.pnpbp.2013.12.018. }\end{array}$ \\
\hline & rs6280 & $\begin{array}{l}\text { ATA haplotype combination for SNPs } \\
\text { rs } 324029, \text { rs } 6280, \text { and rs } 9825563, \\
\text { respectively, was significantly } \\
\text { associated with total amphetamine } \\
\text { dependence patients ( } \mathrm{p}=0.0003 \text { after } \\
10,000 \text { permutations). }\end{array}$ & $\begin{array}{l}\text { A total of } 1060 \text { unrelated Han Chinese subjects } \\
(\mathrm{N}=559 \text { AD patients and } \mathrm{N}=501 \text { controls }) \text { were } \\
\text { screened using the same assessment tool and } \\
\text { genotyped for eight DRD3 polymorphisms. }\end{array}$ & $\begin{array}{l}\text { Kuo SC, Yeh YW, Chen CY, Huang } \\
\text { CC, Chen TY, Yen CH, Liang CS, } \\
\text { Ho PS, Lu RB, Huang SY. Novelty } \\
\text { seeking mediates the effect of DRD3 } \\
\text { variation on onset age of amphetamine } \\
\text { dependence in Han Chinese population. } \\
\text { Eur Arch Psychiatry Clin Neurosci. } \\
\text { 2018 Apr;268(3):249-260. doi: 10.1007 } \\
\text { s00406-016-0754-x. }\end{array}$ \\
\hline & & $\begin{array}{l}\text { Single-marker analyses provided } \\
\text { nominally significant evidence for } \\
\text { associations of rs } 6280 \text { in both heroin } \\
\text { and cocaine addiction. }\end{array}$ & $\begin{array}{l}\text { This study examined the association of } 98 \text { single } \\
\text { nucleotide polymorphisms in } 13 \text { dopamine-related } \\
\text { genes with heroin addiction (OD) and/or cocaine } \\
\text { addiction (CD) in a sample of } \mathrm{N}=801 \text { African } \\
\text { Americans ( } 315 \text { subjects with } \mathrm{OD} \pm \mathrm{CD}, 279 \\
\text { subjects with CD, and } 207 \text { controls). }\end{array}$ & $\begin{array}{l}\text { Levran O, Randesi M, da Rosa JC, } \\
\text { Ott J, Rotrosen J, Adelson M, Kreek } \\
\text { MJ. Overlapping dopaminergic } \\
\text { pathway genetic susceptibility to } \\
\text { heroin and cocaine addictions in } \\
\text { African Americans. Ann Hum Genet. } \\
\text { 2015 May;79(3):188-98. doi: } 10.1111 / \\
\text { ahg.12104. Epub 2015 Feb 27. PubMed } \\
\text { PMID: 25875614; PubMed Central } \\
\text { PMCID: PMC4399004. }\end{array}$ \\
\hline
\end{tabular}


Blum K (2019) Biotechnical development of genetic addiction risk score (GARS) and selective evidence for inclusion of polymorphic allelic risk in substance use disorder (SUD)

\begin{tabular}{|c|c|c|c|c|}
\hline \multirow[t]{3}{*}{ DRD4 } & $\begin{array}{l}\text { Rs180095 48bP repeat } \\
\text { VNTR }\end{array}$ & $\begin{array}{l}521 \mathrm{C} / \mathrm{T} \text { SNP }(\mathrm{rs} 1800955) \text { of the } \\
\text { DRD4 gene showed nominal } \\
\text { association with a possible protective } \\
\text { effect of the } \mathrm{C} \text { allele for heroin } \\
\text { dependence }\end{array}$ & $\begin{array}{l}\mathrm{N}-303 \text { heroin dependent subjects and } \mathrm{N}=555 \\
\text { healthy controls were genotyped for rs } 1800955 \text {, } \\
\text { rs } 936462 \text { and rs } 747302 \text { of the DRD } 4 \text { gene. }\end{array}$ & $\begin{array}{l}\text { Vereczkei A, Demetrovics Z, Szekely A, } \\
\text { Sarkozy P, Antal P, Szilagyi A, Sasvari- } \\
\text { Szekely M, Barta C. Multivariate } \\
\text { analysis of dopaminergic gene variants } \\
\text { as risk factors of heroin dependence. } \\
\text { PLoS One. 2013 Jun 28;8(6):e66592. } \\
\text { doi: } 10.1371 \text { journal.pone.0066592. } \\
\text { PubMed PMID: 23840506; PubMed } \\
\text { Central PMCID: PMC3696122. }\end{array}$ \\
\hline & & $\begin{array}{l}\text { The } D R D 4 \text { polymorphism } 120 \mathrm{bp} \\
\text { tandem duplication, located } 1.2 \mathrm{~kb} \\
\text { upstream of the initiation codon was } \\
\text { analyzed. Statistically significant } \\
\text { associations of polymorphisms in in } \\
D R D 4 \text { with alcoholism were found. }\end{array}$ & $\begin{array}{l}\text { A total of } 90 \text { cases (alcohol dependent males) } \\
\text { and } 122 \text { age and ethnicity matched healthy male } \\
\text { controls were recruited in the study by following } \\
\text { DSM-IV criteria. }\end{array}$ & $\begin{array}{l}\text { Prasad P, Ambekar A, Vaswani M. } \\
\text { Case-control association analysis of } \\
\text { dopamine receptor polymorphisms in } \\
\text { alcohol dependence: a pilot study in } \\
\text { Indian males. BMC Res Notes. } 2013 \\
\text { Oct 17;6:418. doi: } 10.1186 / 1756- \\
\text { 0500-6-418. PubMed PMID: } \\
\text { 24135011; PubMed Central PMCID: } \\
\text { PMC3853477. }\end{array}$ \\
\hline & \multirow[t]{2}{*}{ Rs180095 } & $\begin{array}{l}\text { The purpose of this longitudinal } \\
\text { study was to investigate a genetic } \\
\text { moderation effect of dopamine } \\
\text { receptor- } 4 \text { gene }(D R D 4) \text { alleles that } \\
\text { have } 7 \text { or more repeats on the efficacy } \\
\text { of a preventive intervention to deter } \\
\text { rural African American adolescents' } \\
\text { substance abuse In the so called } \\
\text { control group the AA that carried at } \\
\text { least one copy of the DRD } 4 \text { repeat } \\
\text { initiated drinking. behavior as a risk. }\end{array}$ & $\begin{array}{l}\text { Adolescents }(N=502, M \text { age }=16 \text { years }) \\
\text { were assigned randomly to the Strong African } \\
\text { American Families-Teen (SAAF-T) program or } \\
\text { to a control condition and were followed for } 22 \\
\text { months. }\end{array}$ & $\begin{array}{l}\text { Brody GH, Chen YF, Beach SR, } \\
\text { Kogan SM, Yu T, Diclemente RJ, } \\
\text { Wingood GM, Windle M, Philibert RA. } \\
\text { Differential sensitivity to prevention } \\
\text { programming: a dopaminergic } \\
\text { polymorphism-enhanced prevention } \\
\text { effect on protective parenting and } \\
\text { adolescent substance use. Health } \\
\text { Psychol. 2014 Feb;33(2):182-91. doi: } \\
\text { 10.1037/a0031253. Epub 2013 Feb } 4 . \\
\text { PubMed PMID: 23379386; PubMed } \\
\text { Central PMCID: PMC3695005. }\end{array}$ \\
\hline & & $\begin{array}{l}\text { A random/fixed-effects meta-analyses } \\
\text { using allelic contrasts found that the } \\
\text { DRD4 } 48 \text { BP repeat VNTR associated } \\
\text { with addiction at }<0.06 \text { ) }\end{array}$ & $\begin{array}{l}\text { A meta-analytic comparison of single marker } \\
\text { analysis of the DRD } 448 \text { BP repeat VNTR was } \\
\text { compared } \\
2324 \text { cases vs. } 1932 \text { controls in } 6 \text { independent } \\
\text { studies }\end{array}$ & $\begin{array}{l}\text { Li CY, Zhou WZ, Zhang PW, Johnson } \\
\text { C, Wei L, Uhl GR. Meta-analysis and } \\
\text { genome-wide interpretation of genetic } \\
\text { susceptibility to drug addiction. BMC } \\
\text { Genomics. 2011 Oct 15;12:508. doi: } \\
\text { 10.1186/1471-2164-12-508. PubMed } \\
\text { PMID: 21999673; PubMed Central } \\
\text { PMCID: PMC3215751. }\end{array}$ \\
\hline & Rs180095 & $\begin{array}{l}\text { This longitudinal study found } \\
\text { Alcohol use at age } 33 \text { was predicted } \\
\text { by previous friends' alcohol use } \\
\text { and correlated with current friends' } \\
\text { alcohol use only for carriers of the } \\
\text { DRD4 long allele. The long allele of } \\
\text { DRD4 is associated with increased } \\
\text { susceptibility to peer influences on } \\
\text { alcohol use in young adulthood }\end{array}$ & $\begin{array}{l}\text { Participants (N=340; } 59 \% \text { female; } 98 \% \text { White) } \\
\text { reported on their own and their friends' alcohol } \\
\text { use at four time points between mean ages } 17 \text { and } \\
\text { 33. Multigroup modeling tested differences in } \\
\text { model paths and covariances across high vs. low } \\
\text { risk DRD4 polymorphisms. }\end{array}$ & $\begin{array}{l}\text { Mrug S, Windle M. DRD4 and } \\
\text { susceptibility to peer influence on } \\
\text { alcohol use from adolescence to } \\
\text { adulthood. Drug Alcohol Depend. } \\
\text { 2014 Dec 1;145:168-73. doi: } \\
\text { 10.1016/j.drugalcdep.2014.10.009. } \\
\text { Epub 2014 Oct 23. PubMed PMID: } \\
\text { 25457740; PubMed Central PMCID: } \\
\text { PMC4268151. }\end{array}$ \\
\hline & Rs180095 & $\begin{array}{l}\text { In this study } \mathrm{N}=50 \text { carried } \mathrm{DRD} 47 \mathrm{R} \\
\text { and } \mathrm{N}=91 \text { did not carry the DRD4 } 7 \\
\mathrm{R} \text {. A significant gene-by-environment } \\
\text { interaction suggested that the same- } \\
\text { day association between witnessing } \\
\text { substance use and antisocial behavior } \\
\text { was significantly stronger among } \\
\text { adolescents with, versus without, } \\
\text { with the } D R D 4-7 \mathrm{R} \text { allele. Providing } \\
\text { evidence for risk for SUD. }\end{array}$ & $\begin{array}{l}\text { Young adolescents }(\mathrm{N}=151) \text { at heightened risk for } \\
\text { both exposure to substance use. Adolescents were, } \\
\text { on average, } 13 \text { years of age. DRD } 4 \text { genotype } \\
\text { was determined. They split adolescents into two } \\
\text { groups: (1) those who possessed at least one copy } \\
\text { of the } 7 \mathrm{R} \text { allele on either chromosome versus }(2) \\
\text { those who did not possess a copy of the 7R allele } \\
\text { on either chromosome. }\end{array}$ & $\begin{array}{l}\text { Russell MA, Wang L, Odgers CL. } \\
\text { Witnessing substance use increases } \\
\text { same-day antisocial behavior } \\
\text { among at-risk adolescents: Gene- } \\
\text { environment interaction in a } 30 \text {-day } \\
\text { ecological momentary assessment } \\
\text { study. Dev Psychopathol. } 2016 \\
\text { Nov;28(4pt2):1441-1456. doi: } 10.1017 / \\
\text { S0954579415001182. Epub 2015 Dec } \\
\text { 9. PubMed PMID: 26648004; PubMed } \\
\text { Central PMCID: PMC5330259. }\end{array}$ \\
\hline & Rs180095 & $\begin{array}{l}\text { DRD4 7R more commonly found } \\
\text { in individuals with high quantity/ } \\
\text { frequency of drug use compared with } \\
\text { controls }\end{array}$ & $\begin{array}{l}\text { The DRD4 } 48 \text { BP repeat (7R) was evaluated in } \\
184 \text { substance abusers and } 122 \text { controls }\end{array}$ & $\begin{array}{l}\text { Vandenbergh DJ,Rodriguez LA,Hivert } \\
\text { E,Schiller JH,Villareal G,Pugh } \\
\text { EW,Lachman H,Uhl GR. Long forms } \\
\text { of the dopamine receptor (DRD4) } \\
\text { gene VNTR are more prevalent in } \\
\text { substance abusers: no interaction with } \\
\text { functional alleles of the catechol-o- } \\
\text { methyltransferase (COMT) gene. Am J } \\
\text { Med Genet. 2000 Oct 9;96(5):678-83. }\end{array}$ \\
\hline & Rs180095 & $\begin{array}{l}\text { DSM IV methamphetamine disorders } \\
\text { was assessed in each subject. 7-repeat } \\
\text { allele more commonly found in } \\
\text { methamphetamine abusers than } \\
\text { controls }\end{array}$ & $\begin{array}{l}\mathrm{N}=416 \text { methamphetamine users and } \mathrm{N}=435 \\
\text { controls genotyped for presence vs. absence of } \\
\text { 7- repeat allele }\end{array}$ & $\begin{array}{l}\text { Chen CK,Hu X,Lin SK,Sham } \\
\text { PC,Loh el-W,Li T,Murray RM,Ball } \\
\text { DM. Association analysis of } \\
\text { dopamine D2-like receptor genes and } \\
\text { methamphetamine abuse. Psychiatr } \\
\text { Genet. 2004 Dec;14(4):223-6. }\end{array}$ \\
\hline
\end{tabular}


Blum K (2019) Biotechnical development of genetic addiction risk score (GARS) and selective evidence for inclusion of polymorphic allelic risk in substance use disorder (SUD)

\begin{tabular}{|c|c|c|c|c|}
\hline & $\begin{array}{l}\text { Using individual alleles } \\
\text { and grouping } 5-7 \text { repeats } \\
\text { as "long" }\end{array}$ & $\begin{array}{l}\text { Association of 7-repeat allele and } \\
\text { alcohol dependence in case control } \\
\text { design }\end{array}$ & $\begin{array}{l}\text { Case control design- } 218 \text { cases and } 197 \text { controls, } \\
-76 \text { alcoholics and their parents }\end{array}$ & $\begin{array}{l}\text { Franke P, Wang T, Nöthen MM, Knapp } \\
\text { M, Neith H, Lichtermann D, Meyer } \\
\text { Zur Caprllen K, Sander T, Propping } \\
\text { P, Maier W. DRD4 exon III VNTR } \\
\text { polymorphism: a case-control and } \\
\text { family-based association approach. } \\
\text { Addiction Biology. } 2000 \text { Jan;5(1):289- } \\
\text { 95. }\end{array}$ \\
\hline & Rs180095 & $\begin{array}{l}\text { DSM-IV opioid dependence. } \\
\text { Association of 7-repeat allele and } \\
\text { opioid dependence }\end{array}$ & 141 opioid dependent patients and 110 controls & $\begin{array}{l}\text { Kotler M, Cohen H, Segman R, } \\
\text { Gritsenko I, Nemanov L, Lerer B, } \\
\text { Kramer I, Zer-Zion M, Kletz I, Ebstein } \\
\text { RP. Excess dopamine D4 receptor } \\
\text { (D4DR) exon III seven repeat allele } \\
\text { in opioid-dependent subjects. Mol } \\
\text { Psychiatry. } 1997 \text { May;2(3):251-4. }\end{array}$ \\
\hline & $\begin{array}{l}\text { DRD4 haplotype (including } \\
\text { exon } 3 \text { VNTR) }\end{array}$ & $\begin{array}{l}\text { Association of DRD4 haplotype } \\
\text { (including exon } 3 \text { VNTR) with } \\
\text { methamphetamine abuse and } \\
\text { interaction of exon } 3 \text { VNTR with } \\
\text { COMT } 158 \text { Val/Met polymorphism }\end{array}$ & 228 methamphetamine abusers and 181 controls & $\begin{array}{l}\text { Li T, Chen CK, Hu X, Ball D, Lin SK, } \\
\text { Chen W, Sham PC, Loh el-W, Murray } \\
\text { RM, Collier DA. Association analysis } \\
\text { of the DRD4 and COMT genes in } \\
\text { methamphetamine abuse. Am J Med } \\
\text { Genet B Neuropsychiatr Genet. } 2004 \\
\text { Aug 15;129B(1):120-4. }\end{array}$ \\
\hline & DRD4 5 repeat allele & $\begin{array}{l}\text { DSM-III-R alcohol dependence } \\
\text { Increased frequency of DRD4 } 5 \text { repeat } \\
\text { allele in alcoholics with protective } \\
\text { ALDH2 allele compared with controls } \\
\text { on alcoholics without this protective } \\
\text { factor }\end{array}$ & $\begin{array}{l}655 \text { Japanese alcoholics and } 144 \text { unrelated } \\
\text { controls }\end{array}$ & $\begin{array}{l}\text { Muramatsu T, Higuchi S, Murayama } \\
\text { M, Matsushita S, Hayashida M. } \\
\text { Association between alcoholism and } \\
\text { the dopamine D4 receptor gene. J Med } \\
\text { Genet. } 1996 \text { Feb;33(2):113-5. }\end{array}$ \\
\hline & $\begin{array}{l}4 \text { repeat homozygotes } \\
\text { compared with all others }\end{array}$ & $\begin{array}{l}\text { DSM-IV alcohol dependence in } \\
\text { parents. 4-repeat homozygotes less } \\
\text { common in children of alcoholics }\end{array}$ & $\begin{array}{l}18 \text { children of alcoholics and } 23 \text { children of } \\
\text { nonalcoholic parents }\end{array}$ & $\begin{array}{l}\text { Namkoong K, Cheon KA, Kim JW, } \\
\text { Jun JY, Lee JY. Association study } \\
\text { of dopamine D2, D4 receptor gene, } \\
\text { GABAA receptor beta subunit } \\
\text { gene, serotonin transporter gene } \\
\text { polymorphism with children of } \\
\text { alcoholics in Korea: a preliminary } \\
\text { study. Alcohol. 2008 Mar;42(2):77-81 }\end{array}$ \\
\hline & $\begin{array}{l}\text { Rs } 18009548 b P \text { repeat } \\
\text { VNTR }\end{array}$ & $\begin{array}{l}\text { The long-repeat alleles of the DRD4 } \\
\text { exon } 3 \text { VNTR polymorphism were } \\
\text { found more frequently in the heroin } \\
\text { addicts }(\mathrm{P}=0.019) \text {. }\end{array}$ & $\begin{array}{l}\mathrm{N}=894 \text { male heroin addicts without other } \\
\text { psychiatric disorders, were recruited as subjects. } \\
\text { Another community } \mathrm{N}=180 \text { males were selected } \\
\text { randomly as controls. }\end{array}$ & $\begin{array}{l}\text { Chien CC, Lin CH, Chang YY, } \\
\text { Lung FW. Association of VNTR } \\
\text { polymorphisms in the MAOA } \\
\text { promoter and DRD4 exon } 3 \text { with } \\
\text { heroin dependence in male Chinese } \\
\text { addicts. World J Biol Psychiatry. } \\
\text { 2010 Mar;11(2 Pt 2):409-16. doi: } \\
\text { 10.3109/15622970903304459. }\end{array}$ \\
\hline \multirow[t]{3}{*}{ DAT1 } & base repeat VNTR & $\begin{array}{l}\text { This analysis showed that the } 6 \mathrm{R} 6 \mathrm{R} \\
\text { genotype was associated with crack } \\
\text { cocaine addiction }(\mathrm{OR}=1.844 ; \mathrm{CI}= \\
1.101-3.089 ; \mathrm{p}=0.020)\end{array}$ & $\begin{array}{l}\text { Compared allele and genotype frequencies of a } \\
\text { 30-bp variable number of tandem repeats (VNTR) } \\
\text { polymorphism of the DAT1 gene, located at } \\
\text { intron } 8 \text {, between adult crack cocaine users } \\
\text { and non-addicted individuals. A cross-sectional } \\
\text { sample of N=239 current adult crack abusers or } \\
\text { dependents from in- and outpatient clinics and N= } \\
211 \text { control individuals was collected in Brazil. }\end{array}$ & $\begin{array}{l}\text { Stolf AR, Müller D, Schuch JB, } \\
\text { Akutagava-Martins GC, Guimaraes } \\
\text { LSP, Szobot CM, Halpern R, Kessler } \\
\text { FHP, Pechansky F, Roman T }{ }^{2} \text {. } \\
\text { Association between the Intron } 8 \\
\text { VNTR Polymorphism of the DAT1 } \\
\text { Gene and Crack Cocaine Addiction. } \\
\text { Neuropsychobiology. } 2017 ; 75(3): 141- \\
\text { 144. doi: } 10.1159 / 000485128 .\end{array}$ \\
\hline & 9R allele compared to $10 \mathrm{R}$. & $\begin{array}{l}\text { Variants in DAT VNTR, showed that } \\
\text { the presence of the } 9 \text { - } 9 \text { genotype } \\
\text { significantly increases the risk of } \\
\text { irritability and direct aggressiveness } \\
\text { more than six and } 10 \text { times with } \\
\text { respect to the } 9 \text { - } 10 \text { genotype in heroin } \\
\text { addicts compared to controls. 9-repeat } \\
\text { allele of the DAT polymorphism } \\
\text { confers increased susceptibility to } \\
\text { antisocial - violent behavior and } \\
\text { aggressiveness in heroin addicts. }\end{array}$ & $\begin{array}{l}\text { Polymorphism of a variable number of tandem } \\
\text { repeats (VNTR) in the 3' untranslated region } \\
\text { of exon } 15 \text { of the SLC6 } 63 \text { gene, coding for the } \\
\text { dopamine transporter (DAT). The repeat number } \\
\text { of the DAT polymorphism was assessed in } \mathrm{N}=125 \\
\text { healthy subjects and } \mathrm{N}=104 \text { heroin-dependent } \\
\text { subjects (including } 52 \text { addicted individuals with } \\
\text { violent behavior and criminal records }\end{array}$ & $\begin{array}{l}\text { Gerra G, Garofano L, Pellegrini C, } \\
\text { Bosari S, Zaimovic A, Moi G, Avanzini } \\
\text { P, Talarico E, Gardini F, Donnini C. } \\
\text { Allelic association of a dopamine } \\
\text { transporter gene polymorphism } \\
\text { with antisocial behaviour in heroin- } \\
\text { dependent patients. Addict Biol. } 2005 \\
\text { Sep;10(3):275-81. }\end{array}$ \\
\hline & $9 \mathrm{R}$ allele compared to $10 \mathrm{R}$ & $\begin{array}{l}\text { DAT1, genotype } 9 / 9 \text { was associated } \\
\text { with early opiate addiction. }\end{array}$ & $\begin{array}{l}\text { VNTR polymorphisms of the dopamine } \\
\text { transporter (DAT1) gene were studied in Russian } \\
\text { male opiate addicts. Number of addicts unknown }\end{array}$ & $\begin{array}{l}\text { Galeeva AR, Gareeva AE, Iur'ev } \\
\text { EB, Khusnutdinova EK. VNTR } \\
\text { polymorphisms of the serotonin } \\
\text { transporter and dopamine transporter } \\
\text { genes in male opiate addicts. Mol Biol } \\
\text { (Mosk). } 2002 \text { Jul-Aug;36(4):593-8. }\end{array}$ \\
\hline
\end{tabular}


Blum K (2019) Biotechnical development of genetic addiction risk score (GARS) and selective evidence for inclusion of polymorphic allelic risk in substance use disorder (SUD)

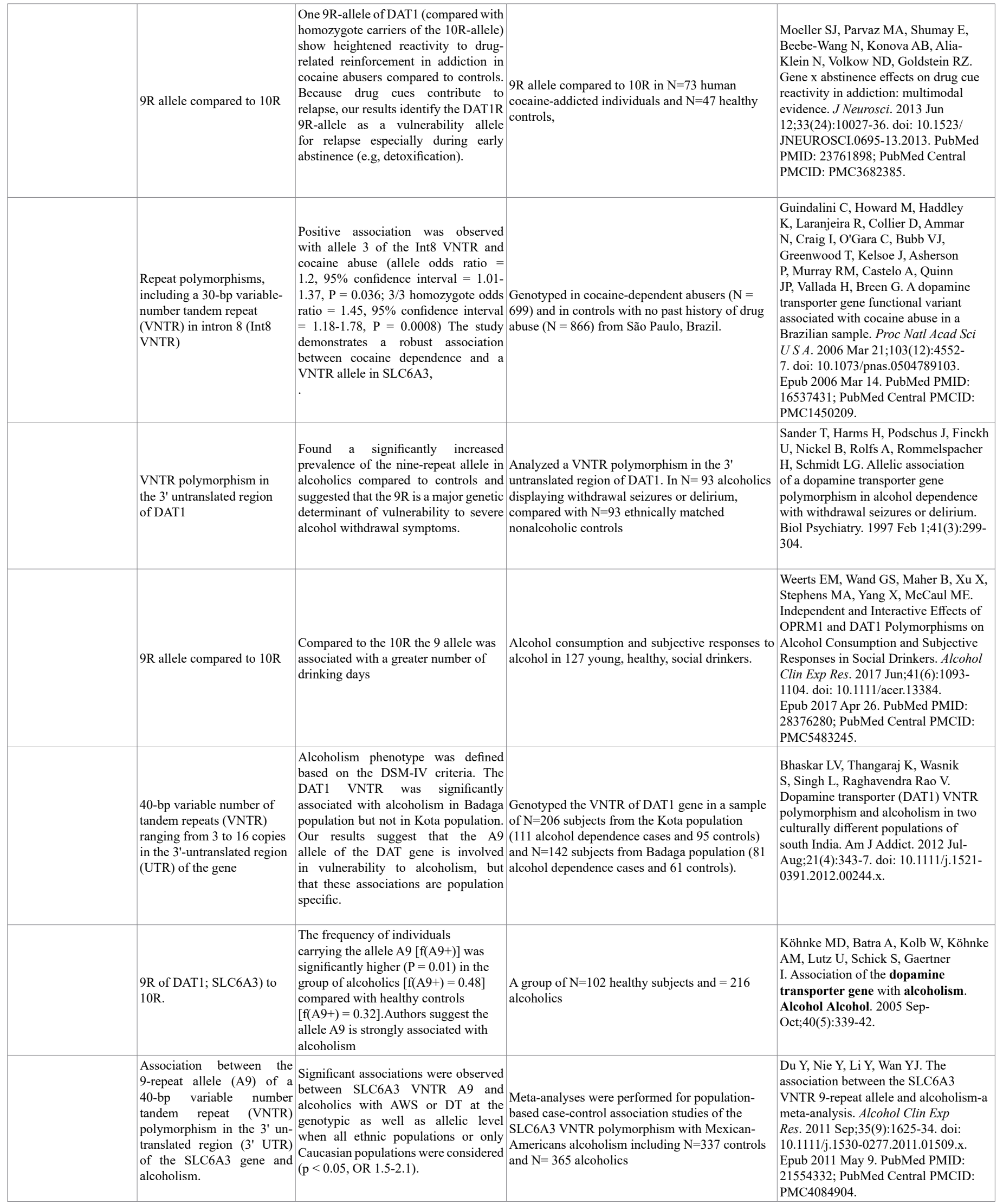


Blum K (2019) Biotechnical development of genetic addiction risk score (GARS) and selective evidence for inclusion of polymorphic allelic risk in substance use disorder (SUD)

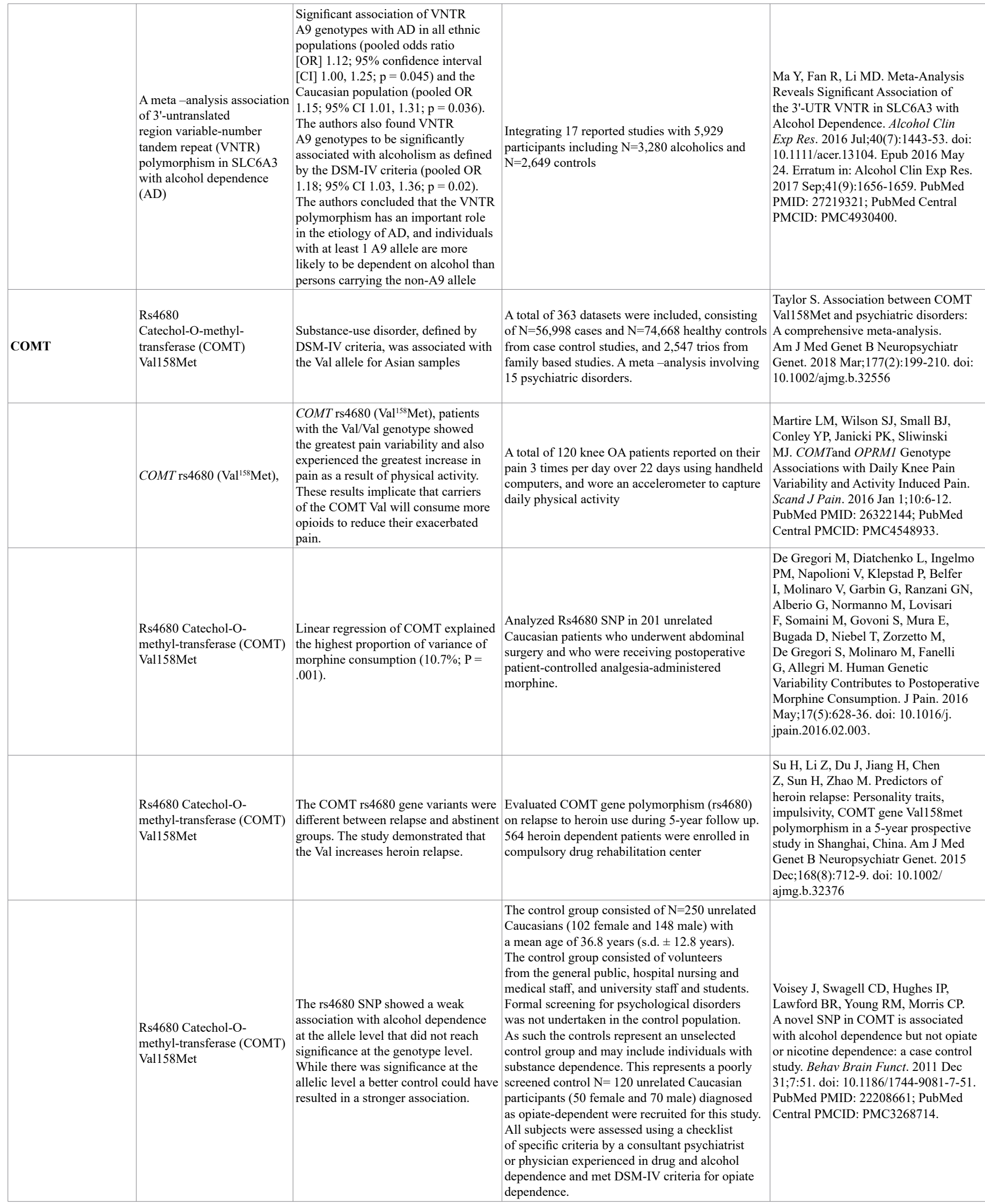


Blum K (2019) Biotechnical development of genetic addiction risk score (GARS) and selective evidence for inclusion of polymorphic allelic risk in substance use disorder (SUD)

\begin{tabular}{|c|c|c|c|c|}
\hline & $\begin{array}{l}\text { Catechol-O- } \\
\text { methyltransferase (COMT) } \\
\text { functional polymorphism, } \\
\text { Val158Met }\end{array}$ & $\begin{array}{l}\text { In women, the COMT Val158 allele } \\
\text { frequency was maximal in alcoholic } \\
\text { smokers }(0.85) \text {, decreasing to } 0.74 \\
\text { in nonalcoholic smokers, } 0.67 \text { in } \\
\text { alcoholic nonsmokers, and } 0.64 \text { in } \\
\text { nonalcoholic nonsmokers (chi } 2= \\
11.1,3 \mathrm{df}, \mathrm{p}=0.011) . \text { Women showed } \\
\text { a main effect of Val158 on smoking } \\
\text { ( } \mathrm{p}=0.003) \text {. Both male and female } \\
\text { alcoholics were more likely to have at } \\
\text { least } 1 \text { Val158 allele compared with } \\
\text { nonalcoholics }(0.95 \text { vs } 0.88, \mathrm{p}<0.05) . \\
\text { Approximately } 30 \% \text { of all participants } \\
\text { were long-term, non-addicted light, } \\
\text { social smokers }(3.6+/-1.7 \text { cigarettes } / \mathrm{d}) ; \\
\text { they had the same Val158Met } \\
\text { frequencies as non-smokers. }\end{array}$ & $\begin{array}{l}\text { The aims of our study were firstly to investigate } \\
\text { patterns of alcohol and tobacco consumption and } \\
\text { comorbidity between alcoholism and smoking } \\
\text { in Plains American Indians. Diagnostic and } \\
\text { Statistical Manual-III-R lifetime diagnoses were } \\
\text { assigned to } 342 \text { community-ascertained Plains } \\
\text { American Indians (201 women, } 141 \text { men). }\end{array}$ & $\begin{array}{l}\text { Enoch MA, Waheed JF, Harris CR, } \\
\text { Albaugh B, Goldman D. Sex differences } \\
\text { in the influence of COMT Val158Met } \\
\text { on alcoholism and smoking in plains } \\
\text { American Indians. Alcohol Clin Exp } \\
\text { Res. } 2006 \text { Mar;30(3):399-406. }\end{array}$ \\
\hline & $\begin{array}{l}\text { A functional polymorphism } \\
\text { (COMTVal158Met) }\end{array}$ & $\begin{array}{l}\text { There was a difference in genotype } \\
\text { frequencies between cannabis users } \\
\text { and controls, including the distribution } \\
\text { of the COMT genotypes (Val/Val, Val/ } \\
\text { Met) }(\mathrm{P}<0.001) \text { and alleles (Val vs, } \\
\text { Met) }(\mathrm{P}<0.01) \text {, }\end{array}$ & $\begin{array}{l}\mathrm{N}=55 \text { cannabis users and } \mathrm{N}=75 \text { normal controls } \\
\text { were enrolled in this study }\end{array}$ & $\begin{array}{l}\text { Baransel Isir AB, Oguzkan S, Nacak } \\
\text { M, Gorucu S, Dulger HE, Arslan A. } \\
\text { The catechol-O-methyl transferase } \\
\text { Val158Met polymorphism and } \\
\text { susceptibility to cannabis dependence. } \\
\text { Am J Forensic Med Pathol. 2008 } \\
\text { Dec;29(4):320-2. doi: } 10.1097 / \\
\text { PAF.0b013e3181847e56. }\end{array}$ \\
\hline & COMT Val158Met & $\begin{array}{l}\text { Substance users and normal controls } \\
\text { significantly differed in allele } \\
\text { frequencies of COMT Val158Met (p } \\
=0.039)\end{array}$ & $\begin{array}{l}187 \text { substance users and } 386 \text { normal controls were } \\
\text { recruited from Northern Taiwan. }\end{array}$ & $\begin{array}{l}\text { Chen CK, Lin SK, Chiang SC, Su LW, } \\
\text { Wang LJ. Polymorphisms of COMT } \\
\text { Val158Met and DAT1 3'-UTR VNTR } \\
\text { in illicit drug use and drug-related } \\
\text { psychiatric disorders. Subst Use } \\
\text { Misuse. 2014 Sep;49(11):1385-91. doi: } \\
\text { 10.3109/10826084.2014.901391. }\end{array}$ \\
\hline & COMT $158 \mathrm{Val} / \mathrm{Met}$ & $\begin{array}{l}\text { The authors found a significant excess } \\
\text { of the high activity Val158 allele in } \\
\text { the methamphetamine abuser group, } \\
\text { consistent with several previous } \\
\text { reports of association of this allele } \\
\text { with drug abuse }\end{array}$ & $\begin{array}{l}\text { A case/control design with } \mathrm{N}=416 \\
\text { methamphetamine abusing subjects and } \mathrm{N}=435 \\
\text { normal controls. }\end{array}$ & $\begin{array}{l}\text { Li T, Chen CK, Hu X, Ball D, Lin SK, } \\
\text { Chen W, Sham PC, Loh el-W, Murray } \\
\text { RM, Collier DA. Association analysis } \\
\text { of the DRD4 and COMT genes in } \\
\text { methamphetamine abuse. Am J Med } \\
\text { Genet B Neuropsychiatr Genet. } 2004 \\
\text { Aug 15;129B(1):120-4. }\end{array}$ \\
\hline & COMT $158 \mathrm{Val} / \mathrm{Met}$ & $\begin{array}{l}\text { COMT Val158Met may affect the } \\
\text { intermediate phenotype of central } \\
\text { dopamine receptor sensitivity. } \\
\text { COMTVal158Met may confer their } \\
\text { risk of alcohol dependence through } \\
\text { reduced dopamine receptor sensitivity } \\
\text { in the prefrontal cortex and hindbrain }\end{array}$ & $\begin{array}{l}\text { Patients }(\mathrm{n}=110) \text { were alcohol dependent } \\
\text { whereas controls }(\mathrm{n}=99) \text { were recruited through } \\
\text { advertisements in regional newspapers. }\end{array}$ & $\begin{array}{l}\text { Schellekens AF, Franke B, Ellenbroek } \\
\text { B, Cools A, de Jong CA, Buitelaar JK, } \\
\text { Verkes RJ. Reduced dopamine receptor } \\
\text { sensitivity as an intermediate phenotype } \\
\text { in alcohol dependence and the role } \\
\text { of the COMT Val158Met and DRD2 } \\
\text { Taq1A genotypes. Arch Gen Psychiatry. } \\
\text { 2012 Apr;69(4):339-48. doi: 10.1001/ } \\
\text { archgenpsychiatry.2011.1335. }\end{array}$ \\
\hline & $\begin{array}{l}\text { Val158Met polymorphism of } \\
\text { the COMT gene }\end{array}$ & $\begin{array}{l}\text { Found a relationship between the } \\
\text { Val158Met polymorphism of the } \\
\text { COMT gene and alcoholism in } \\
\text { male subjects. Found the significant } \\
\text { difference between male alcoholics } \\
\text { and male controls in allele and } \\
\text { genotype frequencies ( }<0,007 \text {; and } \\
\mathrm{p}<0,04 \text { respectively). Confirmed } \\
\text { the relationship between the COMT } \\
\text { polymorphism and alcoholism in the } \\
\text { Czech male population. }\end{array}$ & $\begin{array}{l}\text { Case control study we analyzed DNA samples } \\
\text { from } \mathrm{N}=799 \text { subjects in total ( } 279 \text { male alcoholics } \\
\text { and } 120 \text { female alcoholics, } 151 \text { male controls and } \\
249 \text { female controls). }\end{array}$ & $\begin{array}{l}\text { Serý O, Didden W, Mikes V, Pitelová } \\
\text { R, Znojil V, Zvolský P. The association } \\
\text { between high-activity COMT allele } \\
\text { and alcoholism. Neuro Endocrinol Lett. } \\
\text { 2006 Feb-Apr;27(1-2):231-5. }\end{array}$ \\
\hline OPRM1 & $\begin{array}{l}\text { A118G(rs1799971) } \\
\text { polymorphism }\end{array}$ & $\begin{array}{l}\text { Meta-analysis showed significant } \\
\text { association between this } \\
\text { polymorphism and susceptibility to } \\
\text { opioid dependence in overall studies }\end{array}$ & $\begin{array}{l}\text { Thirteen studies }(\mathrm{n}=9385) \text {, comprising } 4601 \\
\text { opioid dependents and } 4784 \text { controls }\end{array}$ & $\begin{array}{l}\text { Haerian BS, Haerian MS. OPRM1 } \\
\text { rs1799971 polymorphism and opioid } \\
\text { dependence: evidence from a meta- } \\
\text { analysis. Pharmacogenomics. } 2013 \\
\text { May;14(7):813-24. doi: } 10.2217 / \\
\text { pgs.13.57. }\end{array}$ \\
\hline
\end{tabular}


Blum K (2019) Biotechnical development of genetic addiction risk score (GARS) and selective evidence for inclusion of polymorphic allelic risk in substance use disorder (SUD)

\begin{tabular}{|c|c|c|c|}
\hline OPRMI (rs1799971) & $\begin{array}{l}\text { Individuals homozygous for AA at the } \\
\text { OPRMI (rs1799971) polymorphisms } \\
\text { required less postsurgical opioid } \\
\text { compared with those homozygous } \\
\text { for GG (Hedges g, }-0.270 ; 95 \% \\
\text { confidence interval, }-0.433 \text { to }-0.108 \text {; } \\
\mathrm{P}=0.001 \text { ).Implicating more opioids } \\
\text { required with G risk allele. }\end{array}$ & Fifty-one studies included in meta- analysis & $\begin{array}{l}\text { Choi SW, Lam DMH, Wong SSC, Shiu } \\
\text { HHC, Wang AXM, Cheung CW. Effects } \\
\text { of Single Nucleotide Polymorphisms } \\
\text { on Surgical and Postsurgical Opioid } \\
\text { Requirements: A Systematic Review } \\
\text { and Meta-Analysis. Clin J Pain. } 2017 \\
\text { Dec;33(12):1117-1130. doi: 10.1097/ } \\
\text { AJP.0000000000000498. }\end{array}$ \\
\hline OPRMI (rs1799971) & $\begin{array}{l}\text { Ethnicity-specific meta-analyses } \\
\text { revealed that the A118G polymorphism } \\
\text { was significantly associated with } \\
\text { alcohol dependence risk in Asians } \\
\text { (GA vs. AA: odds ratio [OR], 1.73; } \\
95 \% \text { confidence interval [CI], } 1.33- \\
2.25 ; \text { GA+GG vs. AA: OR, } 1.57 ; 95 \% \\
\text { CI, } 1.22-2.02 \text { ), but not in Caucasians } \\
\text { (GA vs. AA: OR, } 1.05 ; 95 \% \text { CI, } 0.75- \\
\text { 1.49; GA+GG vs. AA: OR, } 1.11 ; 95 \% \\
\text { CI, 0.79-1.55). The OPRM1 A118G } \\
\text { polymorphism may contribute to the } \\
\text { susceptibility of alcohol dependence } \\
\text { in Asians }\end{array}$ & $\begin{array}{l}\text { Twelve independent studies with } \mathrm{N}=1900 \\
\text { cases and } \mathrm{N}=2382 \text { controls were included. Five } \\
\text { studies were conducted in Asians and seven in } \\
\text { Caucasians }\end{array}$ & $\begin{array}{l}\text { Chen D, Liu L, Xiao Y, Peng Y, Yang } \\
\text { C, Wang Z. Ethnic-specific meta- } \\
\text { analyses of association between the } \\
\text { OPRM1 A118G polymorphism and } \\
\text { alcohol dependence among Asians and } \\
\text { Caucasians. Drug Alcohol Depend. } \\
\text { 2012 Jun 1;123(1-3):1-6. doi: } 10.1016 / \mathrm{j} \text {. } \\
\text { drugalcdep.2011.10.012. }\end{array}$ \\
\hline $\begin{array}{l}\text { Human } \mu \text {-opioid receptor } \\
\text { variant } 118 \mathrm{~A}>\mathrm{G} \\
(\mathrm{rs} 1799971)\end{array}$ & $\begin{array}{l}\text { Meta-analysis of } 14 \text { studies: Cohen's } \\
\mathrm{d}=0.096 ; \mathrm{p}=0.008) \text {, consisting of } \\
\text { higher opioid dosing requirements } \\
\text { in peri- and post-operative settings. } \\
\text { Cohen is very conservative and as such } \\
\text { the rs } 1799971 \text { due to its small effect } \\
\text { size, the SNP should be regarded as a } \\
\text { part of complex genotypes underlying } \\
\text { pain and analgesia. }\end{array}$ & $\begin{array}{l}\text { Meta-analysis of } 14 \text { studies The population total } \\
\text { was } 3446 \text { ( }=1476 \mathrm{G} \text { carriers and } 1970 \text {-on } \mathrm{G} \\
\text { carriers) }\end{array}$ & $\begin{array}{l}\text { Walter C, Doehring A, Oertel BG, } \\
\text { Lötsch J. } \mu \text {-opioid receptor gene variant } \\
\text { OPRM1 } 118 \text { A }>\text { G: a summary of its } \\
\text { molecular and clinical consequences } \\
\text { for pain. Pharmacogenomics. } 2013 \\
\text { Nov;14(15):1915-25. doi: } 10.2217 / \\
\text { pgs.13.187. }\end{array}$ \\
\hline $\begin{array}{l}\text { OPRM1 } m R N A \text {-expression } \\
\text { in prefrontal cortex }\end{array}$ & $\begin{array}{l}\text { The functional SNP allele } \\
\text { rs1799971-A was associated with } \\
\text { heroin addiction only in the presence } \\
\text { of other haplotypes. }\end{array}$ & $\begin{array}{l}\text { Tested } 103 \text { OPRM1 SNPs for association with } \\
\text { OPRM1 mRNA expression in prefrontal cortex } \\
\text { from } 224 \text { European Americans and African } \\
\text { Americans of the BrainCloud cohort. We then } \\
\text { tested the } 16 \text { putative } \text { cis-quantitative trait loci } \\
\text { (cis-eQTL) SNPs for association with heroin } \\
\text { addiction in the Urban Health Study and two } \\
\text { replication cohorts, totaling 16,729 European } \\
\text { Americans, African Americans, and Australians of } \\
\text { European ancestry. Final analysis dataset included } \\
\mathrm{N}=852 \text { African Americans (307 DSM-IV-defined } \\
\text { cases of heroin/other opioid abuse or dependence } \\
\text { and } 545 \text { controls with no illicit drug abuse or } \\
\text { dependence. }\end{array}$ & $\begin{array}{l}\text { Hancock DB, Levy JL, Gaddis NC, } \\
\text { Glasheen C, Saccone NL, Page GP, } \\
\text { Hulse GK, Wildenauer D, Kelty EA, } \\
\text { Schwab SG, Degenhardt L, Martin NG, } \\
\text { Montgomery GW, Attia J, Holliday } \\
\text { EG, McEvoy M, Scott RJ, Bierut LJ, } \\
\text { Nelson EC, Kral AH, Johnson EO. } \\
\text { Cis-Expression Quantitative Trait } \\
\text { Loci Mapping Reveals Replicable } \\
\text { Associations with Heroin Addiction } \\
\text { in OPRM1. Biol Psychiatry. 2015 } \\
\text { Oct 1;78(7):474-84. doi: 10.1016/j. } \\
\text { biopsych.2015.01.003. Epub 2015 Jan } \\
\text { 29. PubMed PMID: 25744370; PubMed } \\
\text { Central PMCID: PMC4519434. }\end{array}$ \\
\hline $\begin{array}{l}\text { OPRM1 gene, A118G } \\
\text { (rs1799971, Asn40Asp) }\end{array}$ & $\begin{array}{l}\text { OPRM1 A118G SNP G118 allele } \\
\text { carriers showed significantly higher } \\
\text { levels of AD severity as indicated by } \\
\text { the MAST. }\end{array}$ & $\begin{array}{l}\mathrm{N}=121 \text { Alcohol dependent }(\mathrm{AD}) \text { patients and } \mathrm{N}= \\
117 \text { healthy male subjects were included in the } \\
\text { study. }\end{array}$ & $\begin{array}{l}\text { Gürel ŞC, Ayhan Y, Karaaslan Ç, Akel } \\
\text { H, Karaca RÖ, Babaoğlu MÖ, Yaşar Ü, } \\
\text { Bozkurt A, Dilbaz N, Uluğ BD, Demir } \\
\text { B. } \mu \text {-Opioid Receptor Gene (OPRM1) } \\
\text { Polymorphisms A118G and C17T } \\
\text { in Alcohol Dependence: A Turkish } \\
\text { Sample. Turk Psikiyatri Derg. } 2016 \\
\text { Summer;27(2):0. }\end{array}$ \\
\hline $\begin{array}{l}\text { OPRM1 (rs1799971) } \\
\text { polymorphism }\end{array}$ & $\begin{array}{l}\text { Research shows that there are } \\
\text { differences in the genotypes and } \\
\text { alleles of the OPRM1 polymorphism } \\
\text { in the case-control study }\end{array}$ & $\begin{array}{l}\text { An association study of a group of Alcohol } \\
\text { Dependent Syndrome (ADS) patients }(\mathrm{n}=177) \\
\text { and control group consisted of healthy volunteers, } \\
\text { with matched gender and age, and with psychiatric } \\
\text { disorders excluded }(\mathrm{n}=162) \text {. }\end{array}$ & $\begin{array}{l}\text { Samochowiec A, Samochowiec J, } \\
\text { Pełka-Wysiecka J, Kucharska-Mazur J, } \\
\text { Grochans E, Jabłoński M, Bieńkowski } \\
\text { P, Murawiec S, Małecka I, Mak M, } \\
\text { Kołodziej Ł, Heitzman J, Grzywacz A. } \\
\text { The role of OPRM1 polymorphism in } \\
\text { the etiology of alcoholism. Adv Clin } \\
\text { Exp Med. 2019 Feb;28(2):199-202. doi: } \\
\text { 10.17219/acem/78592. }\end{array}$ \\
\hline
\end{tabular}


Blum K (2019) Biotechnical development of genetic addiction risk score (GARS) and selective evidence for inclusion of polymorphic allelic risk in substance use disorder (SUD)

\begin{tabular}{|c|c|c|c|c|}
\hline & $\begin{array}{l}\text { A single gene, OPRM1, } \\
\text { encodes the MOR }\end{array}$ & $\begin{array}{l}\text { Results indicate that } 118 \mathrm{G} \text { allele } \\
\text { carriers reported significantly more } \\
\text { heroin use-related consequences and } \\
\text { heroin-quit attempts, and were more } \\
\text { likely to have sought treatment for their } \\
\text { heroin use than 118AA homozygotes. }\end{array}$ & Caucasian chronic heroin users $(\mathrm{n}=86)$ & $\begin{array}{l}\text { Woodcock EA, Lundahl LH, } \\
\text { Burmeister M, Greenwald MK. } \\
\text { Functional mu opioid receptor } \\
\text { polymorphism (OPRM1 A(118) G) } \\
\text { associated with heroin use outcomes } \\
\text { in Caucasian males: A pilot study. Am } \\
\text { J Addict. 2015 Jun;24(4):329-35. doi: } \\
\text { 10.1111/ajad.12187. Epub 2015 Apr } 24 . \\
\text { PubMed PMID: 25911999; PubMed } \\
\text { Central PMCID: PMC5541380. }\end{array}$ \\
\hline & $\begin{array}{l}\text { A118G rs1799971 } \\
\text { polymorphism }\end{array}$ & $\begin{array}{l}\text { When the authors assessed the } \\
\text { associations of this polymorphism } \\
\text { with the presence or absence of } \\
\text { alcohol use disorder through the } \\
\text { AUDIT score, we found that, after } \\
\text { covariate adjustment, male carriers } \\
\text { of the G allele had an increased risk } \\
\text { of presenting an alcohol pattern } \\
\text { consumption compatible with AUD } \\
(\mathrm{OR}=2.52 ; 95 \% \text { CI: } 1.02-6.24 ; p= \\
0.046) \text {. The conclusion is that these } \\
\text { results suggest that } O P R M 1 \text { gene } \\
\text { polymorphisms are associated with } \\
\text { tobacco and alcohol consumption } \\
\text { in a Spanish population, and this } \\
\text { association could be modulated by } \\
\text { genetic and environmental factors. }\end{array}$ & $\begin{array}{l}\mathrm{N}=763 \text { unrelated individuals ( } 465 \text { women, } 298 \\
\text { men) aged } 18-85 \text { years were recruited between } \\
\text { October } 2011 \text { and April } 2012 \text {. Participants were } \\
\text { requested to answer a } 35 \text {-item questionnaire on } \\
\text { tobacco and alcohol consumption, as well as to } \\
\text { complete the AUDIT and Fagerström tests. }\end{array}$ & $\begin{array}{l}\text { Francès F, Portolés O, Castelló } \\
\text { A, Costa JA, Verdú F. Association } \\
\text { between Opioid Receptor mu } 1 \\
\text { (OPRM1) Gene Polymorphisms and } \\
\text { Tobacco and Alcohol Consumption } \\
\text { in a Spanish Population. Bosn J Basic } \\
\text { Med Sci. 15(2):31-6. doi: 10.17305/ } \\
\text { bjbms.2015.243. PubMed PMID: } \\
\text { 26042510; PubMed Central PMCID: } \\
\text { PMC4469933. }\end{array}$ \\
\hline \multirow[t]{4}{*}{ GABRB3 } & $\begin{array}{l}\text { GABRB3 promotor } \\
\text { Alpha-3 CA-repeat } 181 \\
\text { (downstream) CHr15 }\end{array}$ & $\begin{array}{l}\text { Data suggest that GABRB3 might be } \\
\text { associated with heroin dependence, } \\
\text { and increased expression of GABRB3 } \\
\text { might contribute to the pathogenesis } \\
\text { of heroin dependence. }\end{array}$ & $\begin{array}{l}\text { A case-control association analysis between } \\
\mathrm{N}=576 \text { subjects with heroin dependence }(549 \\
\text { males, } 27 \text { females) and } 886 \text { controls ( } 472 \text { males, } \\
414 \text { females) }\end{array}$ & $\begin{array}{l}\text { Chen CH, Huang CC, Liao DL. } \\
\text { Association analysis of GABRB3 } \\
\text { promoter variants with heroin } \\
\text { dependence. PLoS One. } 2014 \text { Jul } \\
\text { 15;9(7):e102227. doi: } 10.1371 / \text { journal. } \\
\text { pone.0102227. PubMed PMID: } \\
\text { 25025424; PubMed Central PMCID: } \\
\text { PMC4098998. }\end{array}$ \\
\hline & $\begin{array}{l}\text { Chr } \\
-15-R S 26779189(\text { Upstream) } \\
\text { Risk CT }\end{array}$ & $\begin{array}{l}\text { For this allele it was found that the } \\
\text { BRBR3 significantly associated } \\
\text { with both heroin and cocaine risk } \\
(\mathrm{P}<.003) \text {. This study suggests } \\
\text { numerous potential susceptibility } \\
\text { loci (or markers that tag them) in } \\
\text { the glutamatergic and GABAergic } \\
\text { pathways for heroin and cocaine } \\
\text { addiction, in subjects of African } \\
\text { and European ancestry, with partial } \\
\text { overlap in susceptibility loci between } \\
\text { populations and between addictions to } \\
\text { different drugs. }\end{array}$ & $\begin{array}{l}\text { Total population N=1860; N=1142=Heroin } \\
\text { subjects; and } 439 \text { controls ; Eastern European } / \\
\text { middle Eastern }=\mathrm{N}=827 \text { Heroin and } 232 \text { Controls; } \\
\text { African-American (AA) }=315 \text { heroin and } 207 \\
\text { controls; } \mathrm{AA}=279 \text { Cocaine Total } 1860=1142 \mathrm{~h} \text {; } \\
279 \text { cocaine and } 439 \text { controls }\end{array}$ & $\begin{array}{l}\text { Levran O, Peles E, Randesi M, Correa } \\
\text { da Rosa J, Ott J, Rotrosen J, Adelson } \\
\text { M, Kreek MJ. Glutamatergic and } \\
\text { GABAergic susceptibility loci for } \\
\text { heroin and cocaine addiction in subjects } \\
\text { of African and European ancestry. } \\
\text { Prog Neuropsychopharmacol Biol } \\
\text { Psychiatry. 2016 Jan 4;64:118-23. } \\
\text { doi: 10.1016/j.pnpbp.2015.08.003. } \\
\text { Epub 2015 Aug 12. PubMed PMID: } \\
\text { 26277529; PubMed Central PMCID: } \\
\text { PMC4564302. }\end{array}$ \\
\hline & $\begin{array}{l}\text { Receptor beta3 subunit } \\
\text { (GABRB3) } 181 \text { variant }\end{array}$ & $\begin{array}{l}\text { When the DRD2 and the GABRB3 } \\
\text { variants are combined, the risk for } \\
\text { alcoholism is more robust than } \\
\text { when these variants are considered } \\
\text { separately. }\end{array}$ & $\begin{array}{l}\text { Determined in a population-based association } \\
\text { study of Caucasian non-alcoholic and alcoholic } \\
\text { subjects. In severe alcoholics, compared to non- } \\
\text { alcoholics }\end{array}$ & $\begin{array}{l}\text { Noble EP, Zhang X, Ritchie T, Lawford } \\
\text { BR, Grosser SC, Young RM, Sparkes } \\
\text { RS. D2 dopamine receptor and } \\
\text { GABA(A) receptor beta3 subunit genes } \\
\text { and alcoholism. Psychiatry Res. } 1998 \\
\text { Nov 16;81(2):133-47. }\end{array}$ \\
\hline & GABRB3 CHR15 & $\begin{array}{l}\text { All combinations of genes, a count } \\
\text { of the number of hypodopaminergic } \\
\text { genotypes. Hypodopaminergic } \\
\text { functioning predicted drug use in males; } \\
\text { however, in females, a deleterious } \\
\text { environment was the salient predictor. } \\
\text { This preliminary study suggests that it } \\
\text { is possible to identify children at risk } \\
\text { for problematic drug use prior to the } \\
\text { onset of drug dependence. }\end{array}$ & $\begin{array}{l}\text { Variables included in the study were } \\
\text { dopaminergic genes (ANKK1 TaqI A, DRD2 } \\
\text { C957T, DRD4 7R, COMT Val/Met substitution, } \\
\text { and SLC6A3 9R) and a GABAergic gene } \\
\text { (GABRB3). Genotyping adolescent Caucasian } \\
\text { children of alcoholics }(\mathrm{N}=57 \text { males, } \mathrm{N}=54 \\
\text { females; mean age }=14.5 \text { years) }\end{array}$ & $\begin{array}{l}\text { Conner BT, Hellemann GS, Ritchie } \\
\text { TL, Noble EP. Genetic, personality, and } \\
\text { environmental predictors of drug use } \\
\text { in adolescents. J Subst Abuse Treat. } \\
2010 \text { Mar;38(2):178-90. doi:10.1016/j. } \\
\text { jsat.2009.07.004. }\end{array}$ \\
\hline MAOA & $\begin{array}{l}30 \text { BP VNTR-3.5R, 4R DN } \\
\text { repeat polymorphisms }\end{array}$ & $\begin{array}{l}\text { Significant associations of alcohol } \\
\text { dependence with MAOA alleles } \\
\text { (RFLP and DNRP) were found among } \\
\text { the Han Chinese. It is concluded that } \\
\text { MAOA mutations may play a role in } \\
\text { susceptibility to alcoholism among } \\
\text { Han Chinese }\end{array}$ & $\begin{array}{l}\text { Male alcoholic patients and nonalcoholic } \\
\text { comparison subjects among Han Chinese }\end{array}$ & $\begin{array}{l}\text { Hsu YP, Loh EW, Chen WJ, Chen } \\
\text { CC, Yu JM, Cheng AT. Association } \\
\text { of monoamine oxidase A alleles with } \\
\text { alcoholism among male Chinese } \\
\text { in Taiwan. Am J Psychiatry. } 1996 \\
\text { Sep;153(9):1209-11. }\end{array}$ \\
\hline
\end{tabular}


Blum K (2019) Biotechnical development of genetic addiction risk score (GARS) and selective evidence for inclusion of polymorphic allelic risk in substance use disorder (SUD)

\begin{tabular}{|c|c|c|c|c|}
\hline & $\begin{array}{l}30 \text { BP VNTR-3.5R, 4R DN } \\
\text { repeat polymorphisms }\end{array}$ & $\begin{array}{l}\text { High activity 4-repeat allele frequency } \\
\text { Buss Durkee Hostility Inventory } \\
(\text { BDHI) mean total scores were } \\
\text { significantly higher in heroin addicts } \\
\text { than in controls }(\mathrm{p}<0.001)\end{array}$ & $\begin{array}{l}\mathrm{N}=199 \text { male subjects of Italian descent, a sample } \\
\text { comprising } 95 \text { healthy subjects and } \mathrm{N}=104 \\
\text { heroin-dependent subjects }\end{array}$ & $\begin{array}{l}\text { Gerra G, Garofano L, Bosari S, } \\
\text { Pellegrini C, Zaimovic A, Moi G, } \\
\text { Bussandri M, Moi A, Brambilla F, } \\
\text { Mameli A, Pizzamiglio M, Donnini } \\
\text { C. Analysis of monoamine oxidase A } \\
\text { (MAO-A) promoter polymorphism } \\
\text { in male heroin-dependent subjects: } \\
\text { behavioural and personality correlates. } \\
\text { J Neural Transm (Vienna). } 2004 \\
\text { May;111(5):611-21. }\end{array}$ \\
\hline & $\begin{array}{l}\text { Dinucleotide repeat length } \\
\text { polymorphism at the MAOA }\end{array}$ & $\begin{array}{l}\text { A significant correlation between the } \\
\text { presence/absence of the disorder and } \\
\text { the length of the MAOCA-1 repeat } \\
\text { was found in males, but not females, } \\
\text { with "long" alleles (repeat length } \\
\text { above } 115 \text { bp) associated with both } \\
\text { increased risk for the disorder and } \\
\text { lower age of onset of substance abuse. }\end{array}$ & $\begin{array}{l}\text { An association between the liability to early } \\
\text { onset alcoholism/substance abuse and a } \\
\text { recently discovered dinucleotide repeat length } \\
\text { polymorphism at the MAOA gene (MAOCA-1) } \\
\text { was examined using polymerase chain reaction } \\
\text { (PCR). }\end{array}$ & $\begin{array}{l}\text { Vanyukov MM, Moss HB, Yu LM, } \\
\text { Tarter RE, Deka R. Preliminary } \\
\text { evidence for an association of a } \\
\text { dinucleotide repeat polymorphism } \\
\text { at the MAOA gene with early onset } \\
\text { alcoholism/substance abuse. Am J Med } \\
\text { Genet. 1995 Apr 24;60(2):122-6. }\end{array}$ \\
\hline & $\begin{array}{l}\text { High activity allele (L: } 4 \\
\text { repeats }(4 \mathrm{R})) \text { of MAOA- } \\
\text { LPR }\end{array}$ & $\begin{array}{l}\text { MAOA-LPR may have predictive } \\
\text { effects on co-morbid BPD in female } \\
\text { heroin-dependent patients; }\end{array}$ & $\begin{array}{l}\mathrm{N}=296 \quad \text { female heroin-dependent patients } \\
\text { (including } 61 \text { patients with Borderline Personality } \\
\text { Disorder(BPD )and } 235 \text { without BPD) and } \mathrm{N}=101 \\
\text { normal females }\end{array}$ & $\begin{array}{l}\text { Yang M, Mamy J, Wang Q, Liao YH, } \\
\text { Seewoobudul V, Xiao SY, Hao W. The } \\
\text { association of 5-HTR2A-1438A/G, } \\
\text { COMTVal158Met, MAOA-LPR, } \\
\text { DATVNTR and 5-HTTVNTR gene } \\
\text { polymorphisms and borderline } \\
\text { personality disorder in female } \\
\text { heroin-dependent Chinese subjects. } \\
\text { Prog Neuropsychopharmacol Biol } \\
\text { Psychiatry. 2014 Apr 3;50:74-82. doi: } \\
\text { 10.1016/j.pnpbp.2013.12.005. }\end{array}$ \\
\hline & $\begin{array}{l}\text { Transcript factorTFAP2b } \\
\text { regulates MAOA }\end{array}$ & $\begin{array}{l}\text { Results showed that the high- } \\
\text { functioning allele was significantly } \\
\text { more common among the female } \\
\text { alcoholics, compared to the non- } \\
\text { alcoholic controls. This suggest that } \\
\text { high allele would up-regulate MAO-A } \\
\text { Long } 3.5 \text { to } 4 \mathrm{R}\end{array}$ & $\begin{array}{l}\text { Compared a sample of female alcoholics }(\mathrm{n}=107) \text {, } \\
\text { sentenced to institutional care for their severe } \\
\text { addiction, contrasted against a control sample of } \\
\text { adolescent females ( } \mathrm{n}=875)\end{array}$ & $\begin{array}{l}\text { Nordquist N, Göktürk C, Comasco E, } \\
\text { Nilsson KW, Oreland L, Hallman J. } \\
\text { Transcription factor AP2 beta involved } \\
\text { in severe female alcoholism. Brain Res. } \\
\text { 2009 Dec 11;1305 Suppl:S20-6. doi: } \\
\text { 10.1016/j.brainres.2009.09.054 }\end{array}$ \\
\hline \multirow[t]{3}{*}{ SLC6A4(5HTTLPR) } & $\begin{array}{l}\text { 43BP-INDEL/VNTR } \\
\text { CHR17-rs25531 LG, S }\end{array}$ & $\begin{array}{l}\text { By univariate ANOVA, a statistically } \\
\text { significant difference was found in the } \\
\text { onset of AD: the mean age of onset } \\
\text { resulted to be of } 25.4 \text { years in males in } \\
\text { respect to } 28.1 \text { in females. In particular } \\
\text { in males, the early AD onset was } \\
\text { different, in a statistically significant } \\
\text { manner, depending on the presence of } \\
\text { at least one S. }\end{array}$ & $\begin{array}{l}\text { Genotyping of the } 5 \text {-HTTLPR (L/S) and rs } 25531 \\
\text { (A/G) polymorphisms of the SLC6A4 gene was } \\
\text { performed on } \mathrm{N}=403 \text { alcoholics outpatients and } \\
\mathrm{N}=427 \text { blood donors. }\end{array}$ & $\begin{array}{l}\text { Pascale E, Ferraguti G, Codazzo C, } \\
\text { Passarelli F, Mancinelli R, Bonvicini } \\
\text { C, Bruno SM, Lucarelli M, Ceccanti } \\
\text { M. Alcohol dependence and serotonin } \\
\text { transporter functional polymorphisms } \\
\text { 5-HTTLPR and rs25531in an Italian } \\
\text { population. Alcohol Alcohol. 2015 } \\
\text { May;50(3):259-65. doi: 10.1093/alcalc/ } \\
\text { agv014. }\end{array}$ \\
\hline & $\begin{array}{l}\text { promoter region } \\
(5-H T T L P R)(\mathrm{rs} 25531)\end{array}$ & $\begin{array}{l}\text { The genotype frequencies of the } \\
5 \text {-HTTLPR }+(\mathrm{S} / \mathrm{S}, \mathrm{S} / \mathrm{LG}, \mathrm{LG} / \mathrm{LG}) \\
\text { polymorphisms were significantly } \\
\text { higher in opiate-dependent patients } \\
(\mathrm{p}=0.01) \text {. There was a significant } \\
\text { interaction between the TPH1 } \\
\text { A218C A/C and 5-HTTLPR S+ gene } \\
\text { polymorphisms in opiate-dependent } \\
\text { (OR } 2.72, \mathrm{p}=0.01) \text {, }\end{array}$ & $\begin{array}{l}\text { Opiate-dependent patients }(\mathrm{n}=309) \text {, and healthy } \\
\text { controls }(\mathrm{n}=301) \text { were recruited from the Han } \\
\text { Chinese population in Taiwan. }\end{array}$ & $\begin{array}{l}\text { Wang TY, Lee SY, Chung YL, Chen } \\
\text { SL, Li CL, Chang YH, Wang LJ, Chen } \\
\text { PS, Chen SH, Chu CH, Huang SY, } \\
\text { Tzeng NS, Hsieh TH, Lee IH, Chen } \\
\text { KC, Yang YK, Hong JS, Lu RB. TPH1 } \\
\text { and 5-HTTLPR Genes Specifically } \\
\text { Interact in Opiate Dependence but } \\
\text { Not in Alcohol Dependence. Eur } \\
\text { Addict Res. 2016;22(4):201-9. doi: } \\
\text { 10.1159/000444676. }\end{array}$ \\
\hline & $\begin{array}{l}\text { rs25531 polymorphisms of } \\
\text { SLC6A4 gene }\end{array}$ & $\begin{array}{l}\text { The biallelic analysis revealed that the } \\
\text { frequency of 5-HTTLPR (LL/LS/SS) } \\
\text { genotypes was statistically significant } \\
\text { different between drug-dependent } \\
\text { individuals and controls }(\mathrm{p}=0.04)\end{array}$ & $\begin{array}{l}\text { Jordanian drug male addicts of Arab descent (n } \\
=192 \text { ) meeting the Diagnostic and Statistical } \\
\text { Manual of Mental Disorders - Fourth edition } \\
\text { criteria for drug dependence and } 230 \text { healthy } \\
\text { male controls from an ethnically homogenous } \\
\text { Jordanian Arab population were examined. }\end{array}$ & $\begin{array}{l}\text { Al-Eitan LN, Jaradat SA, Qin W, } \\
\text { Wildenauer DM, Wildenauer DD, } \\
\text { Hulse GK, Tay GK. Characterization of } \\
\text { serotonin transporter gene (SLC6A4) } \\
\text { polymorphisms and its association } \\
\text { with drug dependence in a Jordanian } \\
\text { Arab population. Toxicol Ind Health. } \\
\text { 2014 Aug;30(7):598-610. doi: } \\
\text { 10.1177/0748233712462446. }\end{array}$ \\
\hline
\end{tabular}


Blum K (2019) Biotechnical development of genetic addiction risk score (GARS) and selective evidence for inclusion of polymorphic allelic risk in substance use disorder (SUD)

\begin{tabular}{|c|c|c|c|}
\hline Gene & Polymorphism & Location & Risk Allele(s) \\
\hline $\begin{array}{c}\text { Dopamine D1 Receptor } \\
\text { DRD1 }\end{array}$ & $\begin{array}{c}\text { rs4532 } \\
\text { SNP }\end{array}$ & Chr 5 & A \\
\hline $\begin{array}{c}\text { Dopamine D2 Receptor } \\
\text { DRD2 } \\
\end{array}$ & $\begin{array}{c}\text { rs } 1800497 \\
\text { SNP }\end{array}$ & Chr 11 & A \\
\hline $\begin{array}{c}\text { Dopamine D3 Receptor } \\
\text { DRD3 }\end{array}$ & $\begin{array}{c}\text { rs6280 } \\
\text { SNP }\end{array}$ & Chr 3 & $\mathrm{C}$ \\
\hline \multirow{2}{*}{$\begin{array}{c}\text { Dopamine D4 Receptor } \\
\text { DRD4 }\end{array}$} & $\begin{array}{c}\text { rs1800955 } \\
\text { SNP }\end{array}$ & Chr 11 & $\mathrm{C}$ \\
\hline & $\begin{array}{l}48 \text { bases Repeat } \\
\text { VNTR }\end{array}$ & Chr 11, Exon 3 & $7 \mathrm{R}, 8 \mathrm{R}, 9 \mathrm{R}, 10 \mathrm{R}, 11 \mathrm{R}$ \\
\hline $\begin{array}{c}\text { Catechol-O-Methyltransferase } \\
\text { COMT }\end{array}$ & $\begin{array}{c}\text { rs } 4680 \\
\text { SNP }\end{array}$ & Chr 22 & G \\
\hline $\begin{array}{c}\text { Mu-Opioid Receptor } \\
\text { OPRM1 } \\
\end{array}$ & $\begin{array}{l}\text { rs1799971 } \\
\text { SNP }\end{array}$ & Chr 6 & G \\
\hline $\begin{array}{c}\text { Dopamine Active Transporter } \\
\text { DAT1 }\end{array}$ & $\begin{array}{c}40 \text { bases Repeat } \\
\text { VNTR }\end{array}$ & Chr 5, Exon 15 & $3 \mathrm{R}, 4 \mathrm{R}, 5 \mathrm{R}, 6 \mathrm{R}, 7 \mathrm{R}, 8 \mathrm{R}$ \\
\hline $\begin{array}{c}\text { Monoamine Oxidase A } \\
\text { MAOA }\end{array}$ & $\begin{array}{c}30 \text { bases Repeat } \\
\text { VNTR }\end{array}$ & Chr X, Promoter & $3.5 \mathrm{R}, 4 \mathrm{R}$ \\
\hline $\begin{array}{l}\text { Serotonin Transporter } \\
\text { SLC6A4 (5HTTLPR) }\end{array}$ & $\begin{array}{c}43 \text { bases Repeat } \\
\text { INDEL/VNTR } \\
\text { plus rs } 25531 \\
\text { SNP }\end{array}$ & Chr 17 & $\mathrm{LG}, \mathrm{S}$ \\
\hline $\begin{array}{l}\text { GABA(A) Receptor, Alpha-3 } \\
\text { GABRB3 }\end{array}$ & $\begin{array}{l}\text { CA-Repeat } \\
\text { DNR }\end{array}$ & $\begin{array}{c}\text { Chr15 } \\
\text { (downstream) }\end{array}$ & 181 \\
\hline
\end{tabular}

Figure 3. GARS panel

(Regular Size Tip In 109MM Long Dry Tube with Active Drying System) were utilized for sample collection. Individuals collect cells from both cheeks by rubbing the swab at least 25 times on each side of their mouth, and then returned the swab to the specimen tube. For all steps of sample processing, appropriate controls including non-template controls and known DNA standards were included and verified [19].

An index of the genes included in the GARS panel and the specific risk polymorphisms are provided in Figures $4 \mathrm{~A}-4 \mathrm{C}$.

Each polymorphism was selected based on SUD a subset of Reward Deficiency Syndrome (RDS) and a known contribution to a state of low dopaminergic or hypodopaminergic functioning in the brain reward circuitry. Samples were also subject to sex determination using PCR amplification and capillary electrophoresis to detect $A M E L X$ and AMELY (AMELX's intron 1 contains a 6 bp deletion relative to intron 1 of $A M E L Y)$.

DNA was isolated from buccal samples using a Mag-Bind Swab DNA 96 Kit (Custom M6395-01, Omega Bio-Tek, Norcross, GA) with the MagMAX Express-96 Magnetic Particle Processor (Applied Biosystems, Foster City, CA). Extracted DNA was quantified for total human gDNA using the TaqMan RNaseP assay (Life Technologies, Carlsbad, CA) on a QuantStudio 12k Flex (Thermo Fischer Scientific, Waltham, MA).

Testing for genetic variation was performed using 1) Real-Time PCR with TaqMan ${ }^{\circledR}$ allele-specific probes on the QuantStudio 12K Flex, or 2) iPlex reagents on the Agena MassARRAY ${ }^{\circledR}$ system, plus 3) Proflex PCR and size separation using the SeqStudio Genetic Analyzer.

For genotyping the single nucleotide polymorphisms (Figure 4A) with Real-Time PCR with on the QuantStudio 12K Flex, commercially available or custom TaqMan RT-PCR assays (Thermo Fischer Scientific, Waltham, MA) were used (Figure 5 for Assay IDs and context sequences). For each reaction, $2.25 \mu \mathrm{L}$ normalized DNA (10 ng total) was mixed with $2.75 \mu \mathrm{L}$ assay master mix, and then subjected to RTPCR amplification and detection. Manufacturer recommended thermal cycling conditions were utilized, and genotypes were called using TaqMan Genotyper Software v1.3 (Life Technologies, Carlsbad, CA).

For genotyping the single nucleotide polymorphisms with the Agena MassARRAY ${ }^{\circledR}$ system, iPlex reagents were used (Figure 4A for iPlex PCR primer sequences). Primers are multiplex, therefore only one reaction is required for each sample. For each reaction, 2 ul normalized DNA (10 ng total) was mixed with the iPlex Pro PCR cocktail. The reaction was amplified on a ProFlex thermocycler with the Agena manufacturer PCR conditions. Amplified DNA was then SAP treated, followed by an extension. The iPLEX Extension Reaction Product was then desalted using a Dry Resin Method. Samples were then dispensed onto a 96 well SpectroCHIP Array using the MassARRAY Nanodispenser. Genotypes were called using the MassARRAY Analyzer Software.

For fragment genotyping, two multiplexed PCR reactions $(50 \mu \mathrm{L}$ total volume) were required. Reaction A included 5' fluorescently labeled primers forward primers and non-labeled reverse primers for $A M E L O X / Y, D A T 1, M A O A$, and the GABRB3 dinucleotide repeat (with sets at $150 \mathrm{nM}, 120 \mathrm{nM}, 120 \mathrm{nM}$, and $480 \mathrm{nM}$ primer concentrations, respectively). Reaction B included 5 ' fluorescently labeled forward primers and non-labeled reverse primers for DRD4 and the SLC6A4 HTTLPR, all in $120 \mathrm{nM}$ concentrations. For all PCR reactions, $2 \mathrm{ng}$ DNA was amplified with primers, $25 \mu \mathrm{L}$ OneTaq HotStart MasterMix (New England Biolabs, Ipswich, MA), and water. For reaction B, $5 \mu \mathrm{M}$ 7-deaza-dGTP (Thermo Fischer Scientific, Waltham, MA) was added to the above recipe. Primers details are listed in Figure 6.

Amplifications were performed using a touchdown PCR method. An initial $95^{\circ} \mathrm{C}$ incubation for $10 \mathrm{~min}$ was followed by two cycles of $95^{\circ} \mathrm{C}$ for $30 \mathrm{~s}, 65^{\circ} \mathrm{C}$ for $30 \mathrm{~s}$, and $72^{\circ} \mathrm{C}$ for $60 \mathrm{~s}$. The annealing temperature 
Blum K (2019) Biotechnical development of genetic addiction risk score (GARS) and selective evidence for inclusion of polymorphic allelic risk in substance use disorder (SUD)

\begin{tabular}{|c|c|c|c|}
\hline GENE & POLYMORPHISM & VARIANT ALLELES & RISK ALLELE \\
\hline $\begin{array}{c}\text { Dopamine D1 Receptor } \\
D R D 1\end{array}$ & rs4532 & $\mathrm{A} / \mathrm{G}$ & $A$ \\
\hline $\begin{array}{c}\text { Dopamine D2 Receptor } \\
\text { DRD2 }\end{array}$ & rs1800497 & $\begin{array}{c}A / G \\
\text { (A1/A2) }\end{array}$ & $\begin{array}{c}\mathrm{A} \\
\text { (A1) }\end{array}$ \\
\hline $\begin{array}{c}\text { Dopamine D3 Receptor } \\
\text { DRD3 }\end{array}$ & rs6280 & $\mathrm{C} / \mathrm{T}$ & $\mathrm{C}$ \\
\hline $\begin{array}{c}\text { Dopamine D4 Receptor } \\
\text { DRD4 } \\
\end{array}$ & rs1800955 & $\mathrm{C} / \mathrm{T}$ & C \\
\hline $\begin{array}{c}\text { Catechol-O-Methyltransferase } \\
\text { COMT }\end{array}$ & rs4680 & $\begin{array}{c}\text { A/G } \\
\text { (Met/Val) }\end{array}$ & $\begin{array}{c}G \\
(\text { Val) }\end{array}$ \\
\hline $\begin{array}{c}\text { Mu-Opioid Receptor } \\
\text { OPRM1 }\end{array}$ & rs1799971 & $\begin{array}{c}\mathrm{A} / \mathrm{G} \\
\text { (Asn/Asp) }\end{array}$ & $\begin{array}{c}\mathrm{G} \\
\text { (Asp) }\end{array}$ \\
\hline
\end{tabular}

Figure 4A. Single nucleotide polymorphisms (SNPs)

\begin{tabular}{|cccc|}
\hline GENE & POLYMORPHISM & VARIANT ALLELES & RISK ALLELE \\
\hline $\begin{array}{c}\text { Dopamine D4 Receptor } \\
\text { DRD4 }\end{array}$ & rs761010487 & $\begin{array}{c}48 \mathrm{bp} \text { repeat } \\
2 \mathrm{R}-11 \mathrm{R}\end{array}$ & $\geq 7 \mathrm{R}$, long form \\
\hline Dopamine Active Transporter & $\mathrm{rs} 28363170$ & $\begin{array}{c}40 \mathrm{p} \text { repeat } \\
\text { 3R-11R }\end{array}$ & $<9 \mathrm{R}$ \\
\hline DAT1 & $\mathrm{rs} 768062321$ & $\begin{array}{c}30 \mathrm{bp} \text { repeat } \\
2 \mathrm{R}-5 \mathrm{R}\end{array}$ & $3.5 \mathrm{R}, 4 \mathrm{R}, 5 \mathrm{R}$ \\
\hline MAOA & $\mathrm{rs} 4795541$, & $\begin{array}{c}43 \mathrm{bp} \text { repeat, with SNP } \\
\text { L/XL and S, G/A }\end{array}$ & $\mathrm{S}, \mathrm{LG}$ \\
\hline $\begin{array}{c}\text { Serotonin Transporter } \\
\text { SLC6A4 (5-HTTLPR) }\end{array}$ & $\mathrm{rs} 25531$ & & \\
\hline
\end{tabular}

Figure 4B. Simple sequence repeats (Variable number tandem repeats and insertion/deletions)

\begin{tabular}{|cccc|}
\hline GENE & POLYMORPHISM & VARIANT ALLELES & RISK ALLELE \\
\hline GABA(A) Receptor, Alpha-3 & rs764926719 & $\begin{array}{c}\text { CA dinucleotide repeat } \\
171-201 \mathrm{bp} \text { sized fragments }\end{array}$ & 181 \\
\hline
\end{tabular}

Figure 4C. Dinucleotide repeats

\begin{tabular}{|c|c|c|}
\hline ASSAY ID & GENE \& SNP & CONTEXT SEQUENCE \\
\hline \multirow{2}{*}{ C__1011777_10 } & $D R D 1$ & TCTGACTGACCCCTATTCCCTGCTT [G/A] \\
\hline & rs4532 & GGAACTTGAGGGGTGTCAGAGCCCC \\
\hline \multirow{2}{*}{ C__ 7486676_10 } & DRD2, ANKK1 & CACAGCCATCCTCAAAGTGCTGGTC [A/G] \\
\hline & rs1800497 & AGGCAGGCGCCCAGCTGGACGTCCA \\
\hline \multirow{2}{*}{ C___949770_10 } & DRD3 & GCCCCACAGGTGTAGTTCAGGTGGC [C/T] \\
\hline & rs6280 & ACTCAGCTGGCTCAGAGATGCCATA \\
\hline \multirow{2}{*}{ C__7470700_30 } & DRD4 & GGGCAGGGGGAGCGGGCGTGGAGGG [C/T] \\
\hline & rs1800955 & GCGCACGAGGTCGAGGCGAGTCCGC \\
\hline \multirow{2}{*}{ C__25746809_50 } & COMT & CCAGCGGATGGTGGATTTCGCTGGC [A/G] \\
\hline & rs4680 & TGAAGGACAAGGTGTGCATGCCTGA \\
\hline \multirow{2}{*}{ C__8950074_1_ } & OPRM1 & GGTCAACTTGTCCCACTTAGATGGC [A/G] \\
\hline & rs1799971 & ACCTGTCCGACCCATGCGGTCCGAA \\
\hline
\end{tabular}

Figure 5. GARS single nucleotide polymorphism assays information

was decreased every two cycles from $65^{\circ} \mathrm{C}$ to $55^{\circ} \mathrm{C}$ in $2^{\circ} \mathrm{C}$ increments ( 10 cycles total), followed by 30 cycles of $95^{\circ} \mathrm{C}$ for $30 \mathrm{~s}, 55^{\circ} \mathrm{C}$ for $30 \mathrm{~s}$, and $72^{\circ} \mathrm{C}$ for $60 \mathrm{~s}$, and a final 30 -min incubation at $60^{\circ} \mathrm{C}$, then hold at $4^{\circ} \mathrm{C}$. A $10 \mu \mathrm{L}$ aliquot of reaction $\mathrm{B}$ amplicon was further subjected to MspI restriction digest $\left(37^{\circ} \mathrm{C}\right.$ for $1 \mathrm{hr}$ ) to interrogate rs25531 (with $1 \mathrm{U}$ restriction enzyme and $1 \mathrm{X}$ Tango Buffer, Thermo Fischer Scientific, Waltham, MA).

For fragment detection by capillary electrophoresis, reactions 1 and 2 were mixed in a $2: 1$ ratio. $1 \mu \mathrm{L}$ of this amplicon mixture was added to $9.5 \mu \mathrm{L}$ mixed LIZ1200 size standard/formamide (Thermo Fischer Scientific, Waltham, MA recommended concentrations). For detection of rs25531, $1 \mathrm{uL}$ of restriction digest mixture was added to 9.5 $\mu \mathrm{L}$ LIZ1200+formamide. Both mixtures were subjected to capillary electrophoresis on the SeqStudio (run time $60 \mathrm{~min}$, voltage 5000 $\mathrm{V}, 10 \mathrm{sec}$ injection at $1200 \mathrm{~V}$ ) then analyzed with GeneMapper 5 software (Life Technologies, Carlsbad, CA). The patient/clinician who requests the test receives a personalized report discussing the results. The report provides a GARS Score (based on scale 1-22) that is the sum of all risk alleles for that individual. Various substance and nonsubstance behaviors are listed as high, moderate, or low risk behavior frequency for that individual. The reports are designed to help users understand the meaning of their results and any appropriate actions that may be taken. 
Blum K (2019) Biotechnical development of genetic addiction risk score (GARS) and selective evidence for inclusion of polymorphic allelic risk in substance use disorder (SUD)

\begin{tabular}{|c|c|c|c|}
\hline PRIMER & SEQUENCE $\left(5^{\prime}\right.$ to $\left.3^{\prime}\right)$ & 5 ' LABEL & REACTION (nM) \\
\hline AMELO-F & CCC TGG GCT CTG TAA AGA ATA GTG & NED & \multirow{2}{*}{150} \\
\hline AMELO-R & ATC AGA GCT TAA ACT GGG AAG CTG & - & \\
\hline MAO-F & ACA GCC TGA CCG TGG AGA AG & NED & \multirow{2}{*}{120} \\
\hline MAO-R & GAA CGG ACG CTC CAT TCG GA & - & \\
\hline DAT-F & TGT GGT GTA GGG AAC GGC CTG AG & 6FAM & \multirow{2}{*}{120} \\
\hline DAT-R & CTT CCT GGA GGT CAC GGC TCA AGG & - & \\
\hline DRD4-F & GCT CAT GCT GCT GCT CTA CTG GGC & VIC & \multirow{2}{*}{480} \\
\hline DRD4-R & CTG CGG GTC TGC GGT GGA GTC TGG & - & \\
\hline GABRA-F & CTC TTG TTC CTG TTG CTT TCA ATA CAC & NED & \multirow{2}{*}{120} \\
\hline GABRA-R & CAC TGT GCT AGT AGA TTC AGC TC & - & \\
\hline HTTLPR-F & ATG CCA GCA CCT AAC CCC TAA TGT & PET & \multirow{2}{*}{120} \\
\hline HTTLPR-R & GAG GGA CTG AGC TGG ACA ACC AC & - & \\
\hline
\end{tabular}

Figure 6. GARS repeats primer details

\section{Summary of initial GARS study}

We are briefly summarizing herein the first study of an association between the Genetic Addiction Risk Score (GARS) and the Addiction Severity Index -Media Version (ASI-MV) among patients from treatment facilities (submitted for publication).

The initial sample of 393 subjects who provided saliva for genotyping, was drawn, from eight geographically diverse treatment centers in the United States. The available sample size of 273 (69\%) consisted of individuals who had also completed the ASI-MV questionnaire [17]. The alcohol, and drug severity scores in the ASI-MV were determined using a proprietary algorithm developed by Inflexxion. A laboratory located at the Institute for Behavioral Genetics (University of Colorado Boulder) performed standard genotyping for specific polymorphic risk alleles derived from a panel of reward genes. The subjects, participating in the pilot phase of the GARS analysis self-reported their race as White at $88.1 \%(\mathrm{n}=244)$ and were $57.8 \%(n=160)$ male. The average age of the of subjects was 35.3 years $($ S.D. $=13.1$, aximum age $=70$, minimum age $=18$ ). This study is a statistical analysis that compared a number of risk alleles to the ASI-MV alcohol and drug severity score of each subject.

Among the ASI analysis sample the number of risk alleles detected ranged from 3 to 15 , and the average was 7.97 (S.D. = 2.34) with a median of 8.0. Preliminary examination of the relationship between GARS genotype panel and the Alcohol Risk Severity Score using the Fishers Exact Test revealed a significant predictive relationship $\left(\mathrm{X}^{2}\right.$ $=8.84, \mathrm{df}=1, \mathrm{p}=0.0042$ tailed) which remained significant after controlling for age [Hardy-Weinberg Equilibrium intact]. Both age and genetic addiction risk scores were predictive of higher alcohol severity scores as assessed with the ASI-MV. In fact, a lower ASI-score predicted a lower GARS score. To account for non-normality in the distribution, drug scores were transformed to $\left(\log _{10}\right)$ before analysis of the relationship between the GARS panel and ASI-MV Drugs Risk Severity Score. The relationship between the GARS panel and the Drug Risk Severity Score was found to be similar but less robust than the observation for the Alcohol Risk Severity. Preliminary examination revealed a nominally significant relationship $(B=-0.122, t=-1.91$, $\mathrm{p}=0.057-2$ tailed) in this study, following apriori hypothesis of an association of GARS and ASI predictability of risk in which a onetailed analysis revealed $(\mathrm{P}=0.028)$ for the drug severity. The predictive value of GARS was more robust for alcohol risk severity (a score equal or greater that 7) and for drug risk severity (a score equal or greater that 4). A limitation of this study relates to the attempt of matching an objective score (genes) with a score from a subjective self-report (ASI).
These results show the GARS test to be a useful predictor of susceptibility to problematic substance use, especially alcoholism. In future studies using highly screened cohorts eliminating all Reward Deficiency Syndrome (RDS) behaviors, LOD scores will be analyzed for each risk allele to determine weighted associations that could lead to even more accurate predictability of the GARS test.

\section{Population GARS prevalence}

PubMed provides frequency data of major and minor allele, but not population prevalence. SNPedia provides population diversity percentages for homozygous SNP; homozygous normal; and heterozygous for all but one of our SNPs, in the following populations (rs4532; rs1800497; rs6280; rs1800955; rs4680 and rs1799971). Unfortunately, currently, there is no population prevalence data on variable number tandem repeats or dinucleotide repeats (Tables 3 and 4).

\section{Sampling of data retrieval}

Tables 4 and 5 illustrates the utility of the GARS across various ethnic groups in a population of 293 . We are presenting this data as a sampling of types of data collection that could be obtained utilizing the above cited techniques. The prevalence in either $\mathrm{N}$ or $\%$ of each risk allele is displayed in Tables 4 and 5 including: COMT, DRD1, DRD2, DRD3, DRD4, OPM1, DAT1-repeats, MAOA, GABRB3, DRD4repeats and HTTLPR.

\section{Future perspectives}

These data and other analyses of GARS have allowed for the current utilization of precise genetic guided therapy coined "Precision Addiction Management" (PAM ${ }^{\circledR}$ ) [20]. Simply, "Precision Addiction Management" (PAM ${ }^{\oplus}$ ) uses the GARS to customize KB220PAM [21] formulations to deliver putative dopamine homeostasis based on developed algorithms matched to polymorphic results. To date there have been 42 published studies on KB220 related to many RDS behaviors [22]. There is evidence derived from animal and human studies using BOLD neuroimaging and behavioral methodologies that support homeostatic activation of brain dopamine in the reward circuitry by KB220 variants, as well as anti-substance seeking and modification of RDS behaviors [23-28]. RDS encompasses behaviors like PTSD, ADHD, over-eating, shopping, hoarding and related RDS cognitive insults. Combating the drug crisis requires PBM across ethnic groups, to induce dopamine homeostasis to those born with RDS predisposition [29].

Previously Blum developed a RDS inventory (questionnaire) which has been significantly modified by Demetrovics \& Blum to display 29 
Blum K (2019) Biotechnical development of genetic addiction risk score (GARS) and selective evidence for inclusion of polymorphic allelic risk in substance use disorder (SUD)

Table 3. Global Heterozygous prevalence

\begin{tabular}{|c|c|}
\hline SNP & Global Heterozygous Prevalence \\
\hline rs4532 & $32 \%$ \\
\hline rs 1800497 & $46 \%$ \\
\hline rs6280 & $41 \%$ \\
\hline rs 1800955 & Frequency of C allele $=0.42$ \\
Prevalence not available & $42 \%$ \\
\hline & rs4680 \\
\hline
\end{tabular}

Table 4. Prevalence in terms of $\mathrm{N}$ and different ethnic groups

Frequency of Risk Allele (n)

\begin{tabular}{|c|c|c|c|c|c|c|c|c|c|c|c|c|}
\hline & COMT & DRD1 & DRD2 & DRD3 & DRD4 & OPRM1 & $\begin{array}{c}\text { DAT1- } \\
\text { Repeats }\end{array}$ & MAOA & GABRB3 & $\begin{array}{l}\text { DRD4- } \\
\text { Repeats }\end{array}$ & HTTLPR & Total Tested \\
\hline Asian & 5 & 9 & 3 & 5 & 4 & 5 & 0 & 3 & 3 & 1 & 9 & 9 \\
\hline Black or & \multirow{2}{*}{18} & \multirow{2}{*}{40} & \multirow{2}{*}{23} & \multirow{2}{*}{39} & \multirow{2}{*}{24} & \multirow{2}{*}{1} & \multirow{2}{*}{8} & \multirow{2}{*}{16} & \multirow{2}{*}{8} & \multirow{2}{*}{13} & \multirow{2}{*}{30} & \multirow{2}{*}{42} \\
\hline African American & & & & & & & & & & & & \\
\hline Hispanic or Latino & 20 & 25 & 17 & 15 & 16 & 8 & 0 & 20 & 18 & 19 & 22 & 29 \\
\hline Mixed Race & 0 & 1 & 1 & 1 & 1 & 0 & 0 & 0 & 1 & 0 & 1 & 1 \\
\hline Other & 6 & 9 & 2 & 6 & 7 & 0 & 0 & 5 & 4 & 4 & 5 & 9 \\
\hline Unknown & 26 & 30 & 11 & 20 & 21 & 14 & 0 & 24 & 20 & 9 & 29 & 36 \\
\hline White or Caucasian & 224 & 245 & 100 & 157 & 206 & 61 & 4 & 226 & 191 & 88 & 222 & 293 \\
\hline
\end{tabular}

Table 5. Prevalence in terms of $\%$ across and different ethnic groups

Frequency of Risk Allele (\%)

\begin{tabular}{|c|c|c|c|c|c|c|c|c|c|c|c|c|}
\hline & \multirow{2}{*}{ COMT } & \multirow{2}{*}{ DRD1 } & \multirow{2}{*}{ DRD2 } & \multirow{2}{*}{ DRD3 } & \multirow{2}{*}{ DRD4 } & \multirow{2}{*}{ OPRM1 } & DAT1- & \multirow{2}{*}{ MAOA } & \multirow{2}{*}{ GABRB3 } & DRD4- & \multirow{2}{*}{ HTTLPR } & \multirow{2}{*}{ Total Tested } \\
\hline & & & & & & & Repeats & & & Repeats & & \\
\hline Asian & $56 \%$ & $100 \%$ & $33 \%$ & $56 \%$ & $44 \%$ & $56 \%$ & $0 \%$ & $33 \%$ & $33 \%$ & $11 \%$ & $100 \%$ & 9 \\
\hline Black or African American & $43 \%$ & $95 \%$ & $55 \%$ & $93 \%$ & $57 \%$ & $2 \%$ & $19 \%$ & $38 \%$ & $19 \%$ & $31 \%$ & $71 \%$ & 42 \\
\hline Hispanic or Latino & $69 \%$ & $86 \%$ & $59 \%$ & $52 \%$ & $55 \%$ & $28 \%$ & $0 \%$ & $69 \%$ & $62 \%$ & $66 \%$ & $76 \%$ & 29 \\
\hline Mixed Race & $0 \%$ & $100 \%$ & $100 \%$ & $100 \%$ & $100 \%$ & $0 \%$ & $0 \%$ & $0 \%$ & $100 \%$ & $0 \%$ & $100 \%$ & 1 \\
\hline Other & $67 \%$ & $100 \%$ & $22 \%$ & $67 \%$ & $78 \%$ & $0 \%$ & $0 \%$ & $56 \%$ & $44 \%$ & $44 \%$ & $56 \%$ & 9 \\
\hline Unknown & $72 \%$ & $83 \%$ & $31 \%$ & $56 \%$ & $58 \%$ & $39 \%$ & $0 \%$ & $67 \%$ & $56 \%$ & $25 \%$ & $81 \%$ & 36 \\
\hline White or Caucasian & $76 \%$ & $84 \%$ & $34 \%$ & $54 \%$ & $70 \%$ & $21 \%$ & $1 \%$ & $77 \%$ & $65 \%$ & $30 \%$ & $76 \%$ & 293 \\
\hline
\end{tabular}

items. In other work conducted by Demetrovics' group involved in the PGA study, a wide spectrum national study was carried out on approximately 1500 adolescents and young adults. These data will be analyzed for 1) explore the characteristics of RDS addictions; 2) Analyze the relationship between both drug and non-drug addictive behaviors; 3) explore the possible genetic markers for all types of RDS behaviors; 4) provide a genetic map using GARS for RDS type addictive behaviors; 5) explore the possible distinct \& overlapping common psychological and genetic characteristics of different types of substance use and behavioral addictions and 6) Provide a multidisciplinary approach test duplicate possible psychological and genetic interaction effects; 7) develop modifications to the current GARS if necessary based on forthcoming analytic results.

It is agreed that both specific psychological and genetics may play an important role in the development of addiction. For example, studies have indicated that personality traits (e.g. schizoid/avoidance; sensation seeking and impulsivity) are associated with SUD [30], Barnes et al. [31]; Saramon et al. [32] and behavioral addictions [33]. However, the exact mechanisms of how these traits are risk factors of addictions are unknown. To address this conundrum Blum's group over a 50 year sojourn confirmed in several studies the concept of a genetically induced hypodopaminergic trait leasing to reward deficiency syndrome that in turn underlies impulsive and addictive behaviors [34-38]. According to Comings and Blum [38] biogenic model, specific genetic variants can cause dysfunctions in the brain reward cascade [39] evoking a hypodopaminergia. The take home message is that the hypodopaminergic brain requires a "dopamine fix" to feel good to subsequently lead to RDS seeking behaviors. With this stated research directed as suggested by the PGA study, could widen the horizon of addiction like phenotypes both drug and non-drug with novel associations that might lead to new perspectives and assist in the identification of yet unknown correlates of these RDS behaviors.

In order to provide a simple schematic portraying our proposal we hereby submit Figure 7.

\section{Summary}

It is the goal through this novel model that by using PBM the addiction field will have a synergistic tool along with MAT or even alone, to overcome dopamine dysregulation either surfeit (adolescents) or deficit (adults) by the induction of " dopamine homeostasis" to help attenuate SUD by enabling early intervention through genetic testing $[23,24]$.

\section{Author contributions}

The original concept was developed by KB. The original draft was provided by $\mathrm{KB}$ to all $\mathrm{co}$-authors. The entire paper was carefully vetted by all co-authors and approved.

\section{Conflicts of interest}

KB and DS through Igene LLC, own percent ownership Geneus Health, LLC., and in some companies holding patents on genetic 
Blum K (2019) Biotechnical development of genetic addiction risk score (GARS) and selective evidence for inclusion of polymorphic allelic risk in substance use disorder (SUD)

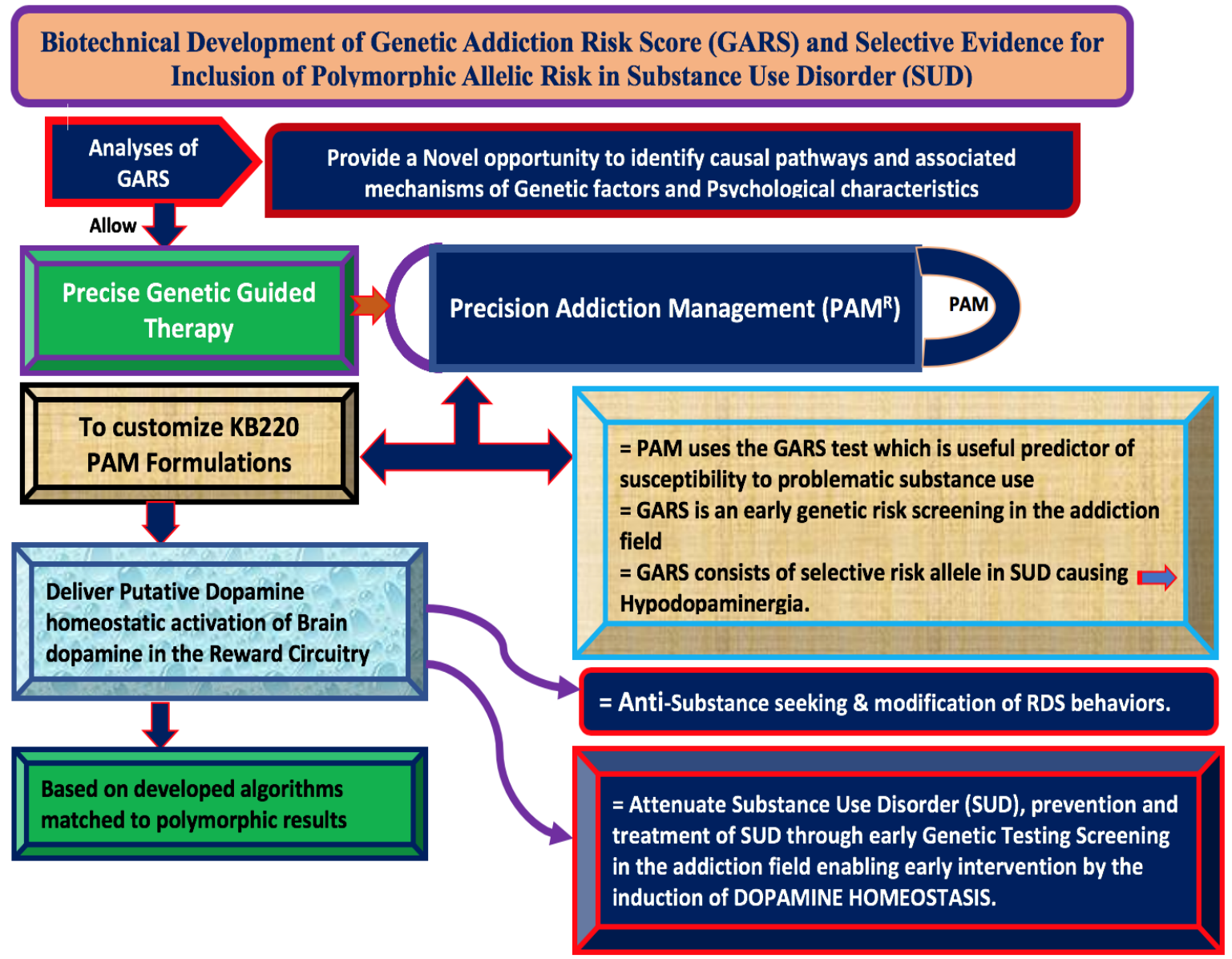

Figure 7. Provides a simple schematic portraying our proposal

testing and KB220PAM. KB and DS have a percentage ownership in Geneus Health LLC., and through Blum's company Synapatmine exclusively licensed Geneus Health for worldwide distribution of the Pro-dopamine regulator (KB220). However, the GARS IP is owned by Geneus Health. KB is founding emeritus Chairman of Geneus Health LLC. He serves with DS on the Geenus Health BOD. Dr. Blum is CSO an d Chairman of the Scientific Advisory Board of Geneus Health. DS is President of Geenus Health LLC. RB, RDB, DB, PKT, MCGL, AKR, and DS are members of Scientific Advisory Board of Geneus Health. JVP is the current Director of the Geneus Genomic Testing Center and LL is a paid consultant of Geneus Health Health .BWD is CEO of Victory Nutrition International a licensee of Geneus Health. The remaining authors declare that the research was conducted in the absence of any commercial or financial relationships that could be construed as a potential conflict of interest.

\section{Acknowledgments}

The authors appreciate the edits by Margaret A. Madigan and the and associated analytics by Moses L. Madigan, and support of the staff of Dominion Diagnostics, LLC and Geneus Health LLC, especially Justin Jones need and Erin Gallagher.

\section{Footnotes}

Funding. The work of RDB was partially supported by the National Institutes of Health grants 1R01NS073884 and 1R21MH073624.
MG-L is the recipient of R01 AA021262/AA/NIAAA NIH HHS/ United States. KB and MG-L are the recipients of R41 MD012318/ NIMHD NIH HHS/United States.

\section{References}

1. Blum K, Sheridan PJ, Wood RC, Braverman ER, Chen TJ, et al. (1996) The D2 dopamine receptor gene as a determinant of reward deficiency syndrome. J R Soc Med 89: 396-400. [ Crossref]

2. Blum K, Fried L, Madigan MA, Giordano J, Modestino EJ, et al. (2017) Critical analysis of white house anti-drug plan. Glob J Addict Rehabil Med 1: 555568.

3. Blum K, Modestino EJ, Neary J, Gondré-Lewis MC, Siwicki D, et al. (2018) Promoting precision addiction management (PAM) to combat the global opioid crisis. Biomed $J$ Sci Tech Res 2: 1-4. [ Crossref]

4. Blum K, Noble EP, Sheridan PJ, Montgomery A, Ritchie T, et al. (1990) Allelic association of human dopamine D2 receptor gene in alcoholism. JAMA 263: 20552060. [ Crossref]

5. Blum K, Oscar-Berman M, Demetrovics Z, Barh D, Gold MS, et al. (2014) genetic addiction risk score (GARS): molecular neurogenetic evidence for predisposition to reward deficiency syndrome (RDS). Mol Neurobiol 50: 765-796. [ Crossref]

6. Smith DE (2012) The process addictions and the new ASAM definition of addiction. $J$ Psychoactive Drugs 44: 1-4.

7. Fischbach-Weiss S, Reese RM, Janak PH (2018) Inhibiting mesolimbic dopamine neurons reduces the initiation and maintenance of instrumental responding. Neuroscience 372: 306-315

8. Blum K, Gold M, Demetrovics Z, Archer T, Thanos PK, et al. (2017) Substance use disorder a bio-directional subset of reward deficiency syndrome. Front Biosci (Landmark Ed) 22: 1534-1548. 
Blum K (2019) Biotechnical development of genetic addiction risk score (GARS) and selective evidence for inclusion of polymorphic allelic risk in substance use disorder (SUD)

9. Blum K, Chen TJ, Meshkin B, Waite RL, Downs BW, et al. (2007) Manipulation of catechol-O-methyl-transferase (COMT) activity to influence the attenuation of substance seeking behavior, a subtype of Reward Deficiency Syndrome (RDS), is dependent upon gene polymorphisms: a hypothesis. Med Hypotheses 69: 1054-1060.

10. Febo M, Blum K, Badgaiyan RD, Baron D, Thanos PK, et al. (2017) Dopamine homeostasis: brain functional connectivity in reward deficiency syndrome. Front Biosci (Landmark Ed) 22: 669-691. [ Crossref]

11. O'Halloran L, Nymberg C, Jollans L, Garavan H, Whelan R, et al. (2017) The potential of neuroimaging for identifying predictors of adolescent alcohol use initiation and misuse. Addiction 112: 719-726. [ Crossref]

12. Ajonijebu DC, Abboussi O, Russell VA, Mabandla MV, Daniels WMU, et al. (2017) Epigenetics: a link between addiction and social environment. Cell Mol Life Sci 74: 2735-2747. [ Crossref]

13. Volkow ND, Li TK (2005) Drugs and alcohol: treating and preventing abuse, addiction and their medical consequences. Pharmacol Ther. 108: 3-17.

14. Els C (2007) Addiction is a mental disorder, best managed in a (public) mental health setting--but our system is failing us. Can J Psychiatry 52: 167-169. [ Crossref]

15. Li CY, Zhou WZ, Zhang PW, Johnson C, Wei L, et al. (2011) Meta-analysis and genome-wide interpretation of genetic susceptibility to drug addiction. BMC Genomics 12: 508 .

16. Gorwood P (2000) Contribution of genetics to the concept of risk status for alcohol dependence. $J$ Soc Biol 194: 43-49.

17. Butler SF, Black RA, McCaffrey SA, Ainscough J, Doucette AM, et al. (2017) A computer adaptive testing version of the Addiction severity index-multimedia version (ASI-MV): the addiction severity CAT. Psychol Addict Behav 31: 265-275.

18. Brown R, Deyo B, Riley C, Quanbeck A, Glass JE, et al. (2017) Screening in trauma for opioid misuse prevention (STOMP): Study protocol for the development of an opioid risk screening tool for victims of injury. Addict Sci Clin Pract 12: 28. [ Crossref]

19. Boór K, Rónai Z, Nemoda Z, Gaszner P, Sasvari-Szekely M, et al. (2002) Noninvasive genotyping of dopamine receptor D4 (DRD4) using nanograms of DNA from substance-dependent patients. Curr Med Chem 9: 793-797. [ Crossref]

20. Blum K, Gondré-Lewis MC, Baron D, Thanos PK, Braverman ER, et al. (2018) introducing precision addiction management of reward deficiency syndrome, the construct that underpins all addictive behaviors. Front Psychiatry 9: 5-48.

21. Blum K, Modestino EJ, Neary J, Gondré-Lewis MC, Siwicki D, et al. (2018) Promoting precision addiction management (PAM) to combat the global opioid crisis. Biomed $J$ Sci Tech Res 2: 1-4. [ Crossref]

22. Blum K (2018) Pro-Dopamine Regulator (KB220) A Fifty-Year Sojourn to Combat Reward Deficiency Syndrome (RDS): Evidence based bibliography (Annotated). $C P Q$ Neurology \& Psychology 1: 01-23.

23. Blum K, Chen ALC, Thanos PK, Febo M, Demetrovics Z, et al. (2018) Genetic addiction risk score $($ GARS () ), a predictor of vulnerability to opioid dependence. Front Biosci (Elite Ed) 10: 175-196. [ Crossref]

24. Blum K, Febo M, Fried L, Li M, Dushaj K, et al. (2017) Hypothesizing that neuropharmacological and neuroimaging studies of glutaminergic-dopaminergic optimization complex (KB220Z) are associated with "dopamine homeostasis" in reward deficiency syndrome (RDS). Subst Use Misuse 52: 535-547. [ Crossref]
25. Blum K, Febo M, Fried L, Baron D, Braverman ER, et al. (2017) Pro-dopamine regulator - (KB220) to Balance brain reward circuitry in reward deficiency syndrome (RDS). J Reward Defic Syndr Addict Sci 3: 3-13. [ Crossref]

26. Blum K, Marcelo F, Dushaj K, Fried L, Badgaiyan RD, et al. (2016) Pro-dopamine regulation (KB220Z $\left.{ }^{\mathrm{TM}}\right)$ " as a long-term therapeutic modality to overcome reduced resting state dopamine tone in opiate/opioid epidemic in America. J Syst Integr Neurosci 2: 162-165. [ Crossref]

27. Blum K (2018) Pro-Dopamine Regulator (KB220) A Fifty-year sojourn to comba reward deficiency syndrome (RDS): Evidence based bibliography (Annotated). $C P Q$ Neurology and Psychology 1: 01-23.

28. Febo M, Blum K, Badgaiyan RD, Perez PD, Colon-Perez LM, et al. (2017) Enhanced functional connectivity and volume between cognitive and reward centers of naïve rodent brain produced by pro-dopaminergic agent KB220Z. PLoS One 12: e 0174774.

29. Blum K, Gondré-Lewis MC, Modestino EJ, Lott L, Baron D, et al. (2019) Understanding the scientific basis of post-traumatic stress disorder (PTSD): Precision behavioral management overrides stigmatization. Mol Neurobiol [ Crossref]

30. Blum K, Braverman ER, Wu S, Cull JG, Chen TJ, et al. (1997) Association of polymorphisms of dopamine D2 receptor (DRD2), and dopamine transporter (DAT1) genes with schizoid/avoidant behaviors (SAB). Mol Psychiatry 2: 239-246.

31. Barnes GE, Murray RP, Patton D, Bentler PM, Anderson RE, et al. (2000) The addiction Prone Personality New York, NY Kluwer Academic /Plenum Publishers

32. Sarramon C, Verdoux H, Schmitt L, Bourgeois M (1999) Addiction and personality traits: sensation seeking, anhedonia, impulsivity. Encephale. 1999 6: 569-75. [ Crossref]

33. Mehroof M, Griffiths MD (2010) Online gaming addiction: the role of sensation seeking, self-control, neuroticism, aggression, state anxiety, and trait anxiety. Cyberpsychol Behav Soc Netw 13: 313-6.

34. Gold MS, Blum K, Febo M, Baron D, Modestino EJ, et al. (2018) Molecular role of dopamine in anhedonia linked to reward deficiency syndrome (RDS) and anti- reward systems. Front Biosci (Schol Ed) 10: 309-325. [ Crossref]

35. Blum K, Febo M, Badgaiyan RD, Demetrovics Z, Simpatico T, et al. (2017) Common neurogenetic diagnosis and meso-limbic manipulation of hypodopaminergic function in reward deficiency syndrome (RDS): Changing the recovery landscape. Curr Neuropharmacol. 15: 184-194. [ Crossref]

36. Blum K, Febo M, Thanos PK, Baron D, Fratantonio J, et al. (2015) Clinically combating reward deficiency syndrome (rds) with dopamine agonist therapy as a paradigm shift: Dopamine for dinner? Mol Neurobiol 52: 1862-1869.

37. Blum K, Thanos PK, Badgaiyan RD, Febo M, Oscar-Berman M, et al. (2015) Neurogenetics and gene therapy for reward deficiency syndrome: are we going to the Promised Land? Expert Opin Biol Ther 15: 973-985. [ Crossref]

38. Comings DE, Blum K (2000) Reward deficiency syndrome: genetic aspects of behavioral disorders. Prog Brain Res 126: 325-341. [ Crossref]

39. Blum K, Febo M, McLaughlin T, Cronjé FJ, Han D, Gold SM (2014) Hatching the behavioral addiction egg: Reward Deficiency Solution System (RDSS) ${ }^{\mathrm{TM}}$ as a function of dopaminergic neurogenetics and brain functional connectivity linking all addictions under a common rubric. J Behav Addict 3: 149-156. [ Crossref]

Copyright: (C2019 Blum K. This is an open-access article distributed under the terms of the Creative Commons Attribution License, which permits unrestricted use, distribution, and reproduction in any medium, provided the original author and source are credited. 